Article

\title{
Energy Poverty and Sustainable Economic Development: An Exploration of Correlations and Interdependencies in European Countries
}

\author{
Blanka Tundys ${ }^{1, * \mathbb{D}}$, Agnieszka Bretyn ${ }^{2}$ and Maciej Urbaniak ${ }^{3}$ (D) \\ 1 Institute of Management, Faculty of Economics, Finance and Management, University of Szczecin, \\ Cukrowa 8, 71-004 Szczecin, Poland \\ 2 Institute of Economics and Finance, Faculty of Economics, Finance and Management, \\ University of Szczecin, ul. Mickiewicza 64, 71-101 Szczecin, Poland; agnieszka.bretyn@usz.edu.pl \\ 3 Faculty of Management, University of Lodz, Matejki 22-26, 90-237 Łódź, Poland; maciej.urbaniak@uni.lodz.pl \\ * Correspondence: blanka.tundys@usz.edu.pl
}

check for

updates

Citation: Tundys, B.; Bretyn, A.; Urbaniak, M. Energy Poverty and Sustainable Economic Development: An Exploration of Correlations and Interdependencies in European Countries. Energies 2021, 14, 7640. https://doi.org/10.3390/en14227640

Academic Editors:

Magdalena Radulescu and David Borge-Diez

Received: 29 September 2021 Accepted: 11 November 2021 Published: 15 November 2021

Publisher's Note: MDPI stays neutral with regard to jurisdictional claims in published maps and institutional affiliations.

Copyright: (c) 2021 by the authors. Licensee MDPI, Basel, Switzerland. This article is an open access article distributed under the terms and conditions of the Creative Commons Attribution (CC BY) license (https:/ / creativecommons.org/licenses/by/ $4.0 /)$.

\begin{abstract}
The problem of energy poverty exists in practically every European country. Its size and scope are determined by a variety of factors, ranging from economic development to the direction of energy and climate policy implementation to cultural factors. Our aim in this paper was to carry out a comparative analysis of indicators related to energy poverty and sustainable development to identify correlations and links between the two issues and determine how they are related. The fact that the analysis was performed for most European countries is new and represents a broad spectrum of research; we were not limited to studies of countries bound by formal political-economic arrangements or by consideration of the degree of economic development. This approach enabled explication of how diverse the situation is in Europe. The research methods used included a critical analysis of the literature and the use of descriptive and mathematical-statistical tools. The main conclusions and findings of the analysis were that in some countries in economically developed Europe, energy poverty is a major problem, and that, in this respect, there are large differences between "old European Union" and "new European Union" countries, and in the countries that do not belong to political-economic structures in Europe. It is clear, from the research, which countries are rapidly and effectively reducing their energy poverty problems and which factors are the determinants of this. These results are linked to the new direction of energy policy and the shift towards more environmentally friendly energy use. In conclusion, it has been possible to identify the causes of energy poverty and how the energy poverty situation in Europe is changing.
\end{abstract}

Keywords: energy poverty; sustainable development; correlation and indexes

\section{Introduction}

Energy poverty can be observed in many regions of the world. Due to its multidimensional nature, it is not just the domain of poor or developing countries. It may seem that in developed, industrialised, and highly electrified European countries, that energy poverty problems are not present. In these countries, the degree of access to electricity, as defined by the World Bank [1], is 100\%. However, it is estimated that more than 50 million households in the European Union experience fuel poverty [2]. It is a problem that affects all European countries to varying degrees. It is important to remember that energy poverty is defined differently in developing countries (i.e., as access to energy sources other than solid fuels including lack of access to modern energy sources) [3,4], and in developed countries (i.e., as economic affordability, referring to high energy costs) [5,6]. In general terms, therefore, energy poverty means that households experience inadequate levels of basic energy services, relating to the provision of heating, cooling, lighting, and energy to run domestic appliances. This situation is related to economic factors that influence the emergence of 
fuel poverty. In theory, the phenomenon of lack of access to energy should not occur, and it should not be a problem for European countries. A significant problem in developed countries is the amount of money spent on energy, combined with low household income. In addition to income, inefficient buildings and appliances and the specific energy needs of energy consumers affect energy costs. Access to basic energy services, whether for heating, lighting, or appliances, contributes to ensuring an adequate standard of living and health for citizens, and the need for this access should guide different policies and the search for solutions to reduce energy poverty. When identifying energy poverty, we need to ask ourselves whether and how it can be avoided, and whether there are differences in the extent of its occurrence for different social groups in countries that implement sustainable economic and climate policies.

With an understanding of how to measure energy poverty, one can look for correlations and relationships, not only between indicators but also between countries, to draw conclusions and make recommendations to eliminate the problem. It is possible to show how the situation has changed over the years and what the causes are. It is necessary to indicate what actions in the field of sustainable development eliminate energy poverty because it affects the functioning of entire economies and is directly related to negative consequences in terms of health and wellbeing (e.g., cardiovascular diseases, respiratory diseases, and/or stress). It can also have an indirect impact on many areas of national economic and climate policy, as well as those related to health, the environment, and economic factors. It is therefore directly linked to the principles of balanced and sustainable development. In this respect, correlations, dependencies, and linkages should be sought, indicating the impact of actions which are aimed at addressing these negative phenomena.

This study aims to examine the correlations that may exist between the implementation of sustainable development principles, based on environmental and macroeconomic indicators, and energy poverty. The analysis seeks to broaden knowledge, identify determinants, and pinpoint causes of energy poverty in Europe. We also consider the possibility of eliminating energy poverty based on a comparison of energy poverty indicators and the implementation of environmental governance in selected European countries. It is of value to consider the reasons for energy poverty in developed countries versus highly industrialised ones: assessing awareness of climate risks, promoting sustainable development and renewable energy, and seeking to identify the causes of energy poverty, as well as potential solutions for the elimination of this phenomenon over time.

The discussion is guided by certain research questions that were chosen for their relevance to the selected European countries, including: (1) Are high energy poverty rates related to household income, expenditure on electricity, heating/cooling, or lighting of households? (2) What relationships exist between the magnitude of energy poverty indicators and sustainable development, in terms of environmental governance in the countries studied (using an indicator for renewable energy sources)? (3) Are there differences in the situation between European countries, and, if so, why?

The study report is structured as follows: Section 1: Introduction, Section 2: Materials and Methods, Section 3: Literature Review, Section 4: Results (numerical and statistical analysis), Section 5: Discussion and Limitations, and Section 6: Conclusions.

\section{Materials and Methods}

The study approach was based on different research methodologies. Based on scientific sources [7], as well as related documents and reports [8], a systematic and critical analysis of the literature was performed, with the objective of synthesizing guidelines and defining phenomena and processes. The literature analysis provided an understanding of the social and economic phenomena related to energy poverty. On this basis, available knowledge was organised and application of selected indicators allowed for comparative analysis, drawing of inferences, and the formulation of recommendations. The contribution to the development of science is the connection, hitherto unexplored, between indicators of energy poverty and sustainable environmental policies, enabling identification of relationships in 
the European countries studied. This type of analysis makes it possible to suggest ways of implementing pro-environmental climate policy which can mitigate energy poverty and take into account potential future changes associated with new sources of energy supply in European countries. The originality and added value of the research are that it goes beyond a single country and examines not just countries of the European Union, which provides a more comprehensive analysis. Various countries were considered in terms of geographic location, including those where energy poverty does not imply that there no possibility of heating rooms, for example, where cooling rooms in the summer is instead problematic. In addition, the economic and political circumstances of selected countries was considered. The article provides a synthesis of evidence and recommendations for further action regarding the implementation of sustainable climate policy and the simultaneous reduction of the scope and level of energy poverty. This was based on statistical data and the use of selected indicators on energy poverty and environmental governance. Quantitative and qualitative analyses were carried out using descriptive and mathematical statistics $[9,10]$. The choice of measurement methods for energy poverty depends on many factors, such as the level of measurement (e.g., national, regional, or European), as well as the availability or comparability of data. In order to investigate the research questions, statistical data from public statistical databases was used.

The research methodology to establish the empirical database involved desktop research that comprised a document and database review of available statistics from international sources. The first component of the methodology was a review of academic articles, reports, and legal acts. The second element was statistical analysis, based on the collection of quantitative data. The data for the survey were taken from the Eurostat database, the World Bank database, and the World Health Organization database. The time frame for the research covered 2011-2019 for 35 European economies, 27 of which were members of the European Union; the remainder included Albania, Iceland, Kosovo, Norway, the United Kingdom, Montenegro, North Macedonia, Switzerland, Serbia, and the Ukraine. Such an approach to the research problem, covering up to 37 European countries, allowed for a broader spectrum of research on energy poverty, covering almost the entire population of Europe.

Using available public statistics, a comparative analysis of the countries studied in the period under review was performed in terms of selected characteristics affecting fuel poverty. The following characteristics were compared across countries and time: percentage of households using clean fuel for cooking; inability to keep the home adequately warm; average electricity prices per household; electricity, gas, and other fuel expenditure of households; arrears on utility bills; and the share of renewable energy in final gross energy consumption.

In order to answer the research questions posed, regression and correlation analyses were performed. At the first stage, using correlograms, it was verified if there was no curvilinear relationship between the examined variables. Points of researched features were concentrated along straight lines, therefore the assumption of linearity of relationships was made. Ordinary linear regression is the most frequently used technique for estimating energy poverty factors, and therefore was used in this paper. Not all explanatory variables of energy poverty were available or accurately measured by the available statistical methods. Therefore, several variables were selected. For each of the analysed countries, the impacts of selected independent variables were examined, including: GDP per capita (i.e., the economic dimension of sustainable development); share of renewable energy in gross final energy consumption (i.e., the environmental dimension of sustainable development); electricity, gas, and other fuel expenditure of households; and the energy poverty rate, represented by the inability to keep a home adequately warm. In order to assess the correlations between the dependent variables and the independent variables, the Pearson correlation was used.

$$
r_{\mathrm{xy}}=\frac{\operatorname{cov}(x, y)}{S x S y} \cdots \cdots \cdots r_{\mathrm{xy}} \in[-1,1]
$$


where:

$\operatorname{cov}(x, y)$-covariance between the $\mathrm{x}$ and $\mathrm{y}$ features

$S x, S y-$ standard deviations of $\mathrm{x}$ and $\mathrm{y}$ features.

The correlations obtained between variables included:

- GDP per capita and household spending on electricity, gas, and other fuels;

- GDP per capita and the share of renewable energy in gross energy consumption;

- Household expenditure on electricity, gas, and other fuels and the share of renewable energy in gross energy consumption.

Figure 1 presents framework of correlation between variables.

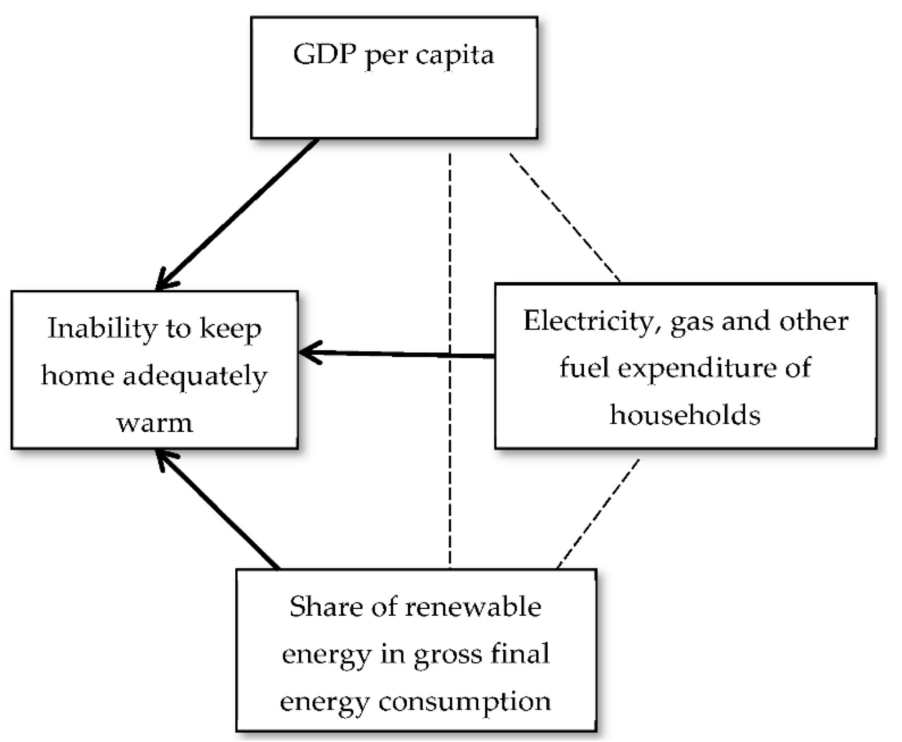

Figure 1. Framework of correlations between variables. Source: own prepared.

To verify the relationship between the studied variables, statistical hypotheses and alternative hypotheses were posed to determine if the null hypotheses could be rejected at the alpha level of significance (alpha $=0.05)$. The null hypothesis tested was:

Hypothesis 0 (H0). Pearson's correlation coefficient $=0$.

Equivalent to no relationship between the analysed variables, against the alternative hypothesis:

Hypothesis 1 (H1). Pearson's correlation coefficient $\neq 0$.

Which states that there is a relationship between the variables under study.

Then their statistical significance was confirmed using the Student's $t$-test at the significance level $=0.05$.

Microsoft Excel and Statistica 13.1 (TIBCO Software Inc., Palo Alto, CA, USA) were used to prepare basic statistics and to conduct the correlational analyses. 


\section{Literature Review}

\subsection{Sustainable Economic Development: An Indicator-Based Approach}

The principles of sustainable development are an approach to economic development that encompasses environmental, social, and economic aspects. The aim is to maintain balance in these areas, ensuring that, at the current level of civilisation, sustainable development is possible, i.e., development in which the needs of the present generation can be met without reducing the chances of future generations to satisfy theirs [11]. To facilitate data comparability, indicators of sustainable development have been created as information and diagnostic tools that facilitate the evaluation and management of social, economic, and environmental spheres at local, regional, national, community, and global levels.

Ways of measuring sustainable development are widely described in the literature $[12,13]$. When analysing and comparing the implementation of sustainable development in the European Union, a set of indicators was used in 10 areas that reflect the challenges of the EU sustainable development strategy. In the context of the discussion and research presented in this article, the most important are those related to climate change and energy. The indicators are arranged hierarchically, covering headline targets and operational targets, with further subdivision into those relating to actions in a particular context. Another approach divides indicators by governance. Thus, within environmental governance, there are thematic areas (e.g., climate change, energy, air protection, marine ecosystems, freshwater resources, land use, biodiversity, and waste management), within which indicators are distinguished. In this respect, four relating to energy are of interest in the context of the current study [14]:

(1) Energy from renewable sources in gross final energy consumption;

(2) Biofuels in transport fuel consumption;

(3) Energy self-sufficiency;

(4) Fixed capital formation in nonconventional energy sources.

Indicator (1) was used in the context of empirical research and answering questions. Using the determinants contained in the Agenda for Sustainable Development [15], goal 1, on social exclusion, and goal 7, whose essence is to ensure access to affordable, reliable, and modern energy services, and the indicators that describe them, can serve as a basis for a comparative analysis of energy poverty and sustainable development. The essence and goal of SDG 7 are to eradicate energy poverty. The measurement system is extremely broad and includes various components. Figure 2 indicates the 17 sustainable development goals.

To simplify the study, indicators with a high degree of generality have been selected, but they can be readily linked to energy poverty indicators. The set of indicators is not exhaustive; there are additional indicators published in environmental reports. 


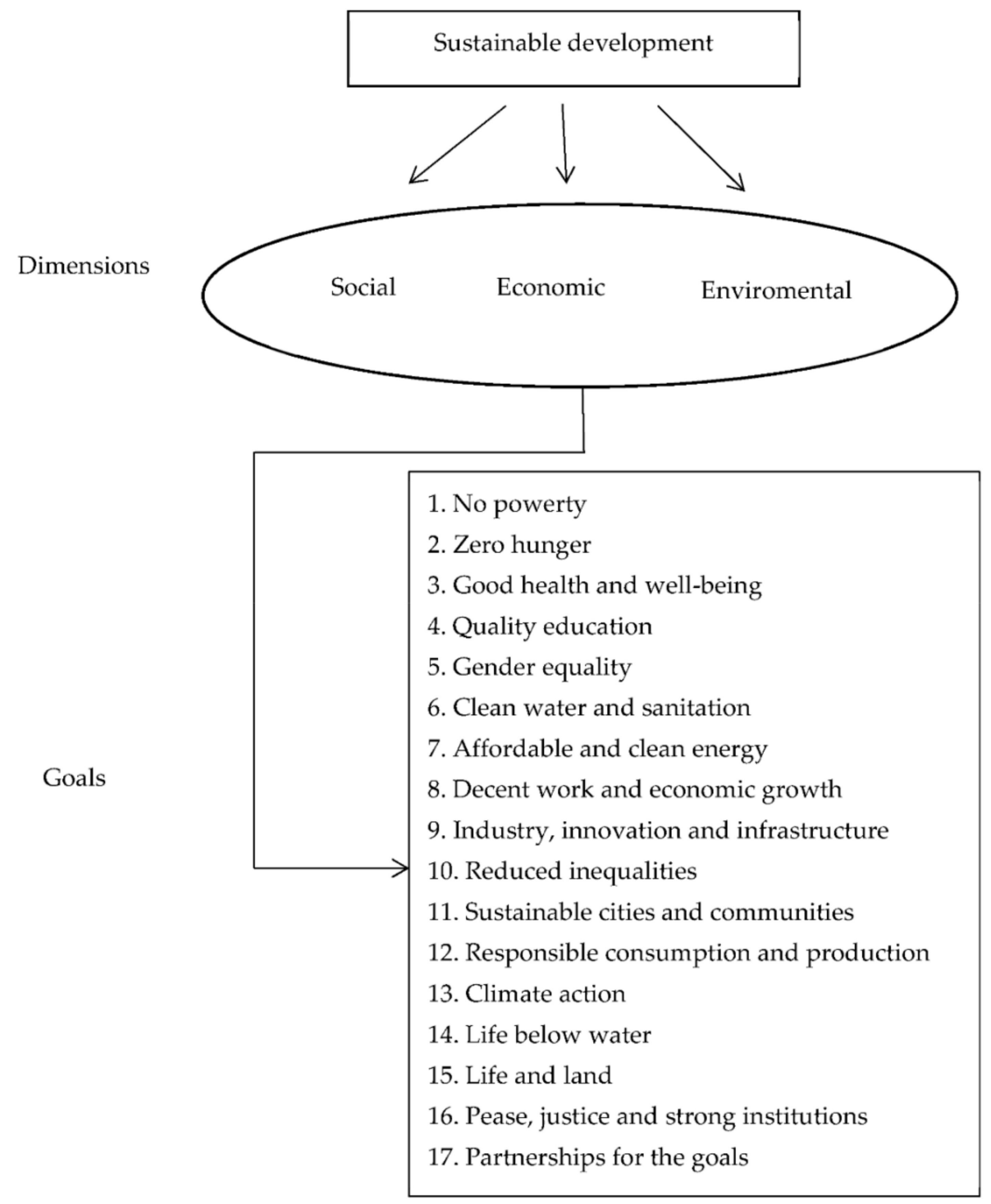

Figure 2. Sustainable development goals. Source: [16].

\subsection{Energy Poverty—Definition, Measurement, and Indicators}

Energy poverty is a multidimensional concept defined in different ways. The literature indicates that it occurs when, for example, the energy costs incurred to maintain satisfactory heating conditions are greater than $10 \%$ of income [17]. This threshold has been used in many scientific studies [18-21]. In definitions of energy poverty, much attention is devoted to maintaining a minimum specified temperature $[22,23]$. The inhabitants of households in which there are difficulties in meeting various types of energy needs are considered energy poor. This includes not only problems with access to electricity, but also heating and hot water. From another perspective, energy poverty can be understood as the inability of a household to provide the required level of energy services at home [24]. However, it is not just the provision of adequate heat or the cost of maintaining heating conditions that define fuel poverty. Low income and high costs (presented as an indicator, LIHC) can be considered [25]. Energy purchase costs can also be considered. In another approach, dependencies can be compared and identified in the context of the use of smart technologies and the use of different charging schemes for energy use [26]. Energy poverty also includes issues related to the socioeconomic status of the inhabitants [27]. It can also be understood as a lack of sufficient choices for appropriate, low-cost, reliable, high-quality, safe, and environmentally friendly energy services [28-30]. Energy poverty means that households 
cannot afford to buy enough energy to meet their domestic needs [31]. Recent perspectives on the forces driving energy poverty have introduced to the definition a wider range of dimensions, interpreting energy poverty as a systemic challenge connected to broader socio-technical and governance infrastructures [32]. Energy poverty can also be defined based on the physical availability of energy services or on a hybrid of the availability of energy supply and problems in paying for it [33].

The causes of energy poverty, as well as the consequences, are many. The most common identified in the literature include technical causes, economic causes, and causes related to attitudes towards the efficient and proper use of energy [30]. However, fuel poverty is a situation of material deprivation that goes beyond income poverty [34].

Most often several indicators are used to measure energy poverty, as one indicator is insufficient to capture the whole of the problem. A set of indicators should be used to assess energy poverty as each can reflect a different aspect of the phenomenon. The measurement can be based on both objective and subjective measures [35]. Their interpretation should be carried out jointly. Approaches to measuring fuel poverty can be divided into two; it is, for example, often suggested in the literature that measurement can be performed based either on an expenditure or a consensual approach [36]. However, the exact definition of fuel poverty depends on the measurement technique [37]. The datasets and indicators of energy poverty are based on analyses available from the Eurostat EU-SILC databases [38]. Dynamic models that consider differences in temperature over time and space, and energy prices are used to measure energy poverty [39]. Issues and indicators based on household expenditure are explored much less often. In a macro-economic context, these include energy consumption in the residential sector. Consideration of energy poverty should not be considered only in a monetary context [40]. Hills [41] suggested that households are considered energy-poor if their energy costs are above the median cost for all households and, if they stay at that level, the remainder of their income would take them below the official poverty line [42]. In addition to these direct causes, structural determinants can be identified, which can be understood in terms of governmental, political, and social aspects, among others, that have the potential to affect health and equity related to the EP without being the main target of policies in these sectors [43]. Measurement can be based on expenditure, temperature, outcome, etc. [36].

Energy poverty can be broken down into five basic dimensions (Table 1). The literature on energy poverty is extremely rich. It very often points to three basic determinants of this phenomenon: low household income, low energy efficiency of the dwelling and home appliances, and high energy prices.

One of the most widely used measurement systems for energy poverty is the operationalisation of the EU Energy Poverty Observatory (EPOV) data. In this respect, subprimary and secondary indicators can be used. Primary indicators are related to limitations in access to energy services and household income and/or expenditure on energy. Secondary indicators are relevant to the nature and understanding of the problem but do not directly relate to the indicators of fuel poverty itself. They will include energy prices and housing data. A list of indicators and their brief characteristics can be found in Table 2 .

Measuring energy poverty can be complex [47], based on multiple socioeconomic factors [48], or by examining the structural possibility of energy poverty [43]. Analysis of the literature indicates that research on the study of fuel poverty is dominated by static analyses that do not allow for a forward-looking view of developments [37]. Therefore, it is important to undertake research linking areas to draw conclusions and indicate further directions for research and decision-making in economic development and sectoral policies (including climate and economic policies). This involves linking energy poverty indicators with balanced development. 
Table 1. Main indicators and areas of energy poverty descriptions.

\begin{tabular}{|c|c|c|c|}
\hline Abbreviation & Acronym & Indicator & Energy Poverty for Households \\
\hline LIHC & LIHC & Low income, high cost & $\begin{array}{l}\text { Household is energy-poor if its available income after accounting for } \\
\text { energy costs is lower than a certain threshold. The household has high } \\
\text { required energy costs (above the national median level) and low } \\
\text { income. The required energy cost is the expenditure needed to meet } \\
\text { the energy needs given the household's characteristics. } \\
\text { The low-income threshold is below the 30th percentile of equivalent } \\
\text { income and is below the individual income } \\
\text { threshold, which takes into account the housing situation. }\end{array}$ \\
\hline High actual cost & $2 \mathrm{M}$ & $\begin{array}{l}\text { A high share of income } \\
\text { spent on energy }\end{array}$ & $\begin{array}{l}\text { The household is energy-poor if its share of income spent on energy is } \\
\text { above a certain threshold. The household spends a high share of its } \\
\text { income on actual energy costs (more than twice the national median } \\
\text { level, ' } 2 \mathrm{M}^{\prime} \text { ). }\end{array}$ \\
\hline Bills difficulties & Bills & $\begin{array}{l}\text { Inability to pay } \\
\text { utility bills }\end{array}$ & Household members have trouble paying their utility bills on time. \\
\hline Housing faults & Leaks & $\begin{array}{l}\text { Presence of leaks, } \\
\text { damp, or rot }\end{array}$ & $\begin{array}{l}\text { Household members live in a dwelling with a leaking roof; damp walls, } \\
\text { floors, or foundations; or rot in the window frames or floors. }\end{array}$ \\
\hline $\begin{array}{l}\text { Not warm } \\
\text { enough }\end{array}$ & Warm & $\begin{array}{l}\text { Inability to keep the } \\
\text { home adequately warm }\end{array}$ & $\begin{array}{l}\text { Household members report that the dwelling is not warm enough in } \\
\text { the winter. }\end{array}$ \\
\hline
\end{tabular}

Source: own elaborations based on [44-46].

Table 2. Energy poverty (EPOV) indicators.

\begin{tabular}{c}
\hline Indicator \\
\hline Arrears on utility bills \\
Low absolute energy expenditure (M/2) \\
High share of energy expenditure in \\
income (2M) \\
Inability to keep home \\
adequately warm
\end{tabular}

Fuel oil prices

Biomass prices Coal prices

Household electricity prices

District heating prices

Household gas prices

Dwelling comfortably cool during summertime

Number of rooms per person, owners

Dwelling comfortably warm during wintertime

Number of rooms per person, renters Dwellings in densely populated areas

Number of rooms per person, total

Dwellings in intermediately populated areas

Poverty risk

Dwellings with energy label A

\section{Measurement}

Primary Indicators

Share of (sub)population having arrears on utility bills Share of households whose absolute energy expenditure is below half the national median.

The $2 \mathrm{M}$ indicator presents the proportion of households whose share of energy expenditure in income is more than twice the national median share.

Share of (sub)population not able to keep their home adequately warm.

\section{Secondary Indicators}

Average household prices per kWh generated from fuel oil

Average household prices per kWh generated from biomass

Average household prices per $\mathrm{kWh}$ generated from coal

Electricity prices for household consumers, band DC 2500-5000 kWh/year consumption, all taxes and levies included

Average household prices per $\mathrm{kWh}$ from district heating

Natural gas prices for household consumers, band 20-200 GJ consumption, all taxes and levies included

Share of population, based on the question 'Is the cooling system efficient enough to keep the house cool?' and/or 'Is the house sufficiently insulated against the heat?'

The average number of rooms per person in owned dwellings

Share of population, based on the questions "Is the heating system efficient enough to keep the dwelling warm?" and "Is the dwelling sufficiently insulated against the cold?"

The average number of rooms per person in rented dwellings

Share of dwellings located in densely populated areas (at least 500 inhabitants $/ \mathrm{km}^{2}$ )

The average number of rooms per person in all dwellings

Share of dwellings located in intermediately populated areas (between 100 and 499 inhabitants $\left./ \mathrm{km}^{2}\right)$

People at risk of poverty or social exclusion (\% of the population) Share of dwellings with an energy label A 
Table 2. Cont.

\begin{tabular}{|c|c|}
\hline Indicator & Measurement \\
\hline Energy expenses, income quintile 1 & $\begin{array}{l}\text { Consumption expenditure for electricity, gas, and other fuels as a share of income for } \\
\text { income quintile } 1\end{array}$ \\
\hline Energy expenses, income quintile 2 & $\begin{array}{l}\text { Consumption expenditure for electricity, gas, and other fuels as a share of income for } \\
\text { income quintile } 2\end{array}$ \\
\hline Energy expenses, income quintile 3 & $\begin{array}{l}\text { Consumption expenditure for electricity, gas, and other fuels as a share of income for } \\
\text { income quintile } 3\end{array}$ \\
\hline Energy expenses, income quintile 4 & $\begin{array}{l}\text { Consumption expenditure for electricity, gas, and other fuels as a share of income for } \\
\text { income quintile } 4\end{array}$ \\
\hline Energy expenses, income quintile 5 & $\begin{array}{l}\text { Consumption expenditure for electricity, gas, and other fuels as a share of income for } \\
\text { income quintile } 5\end{array}$ \\
\hline Equipped with air conditioning & Share of the population living in a dwelling equipped with air conditioning facilities \\
\hline Equipped with heating & Share of the population living in a dwelling equipped with heating facilities \\
\hline Excess winter mortality/deaths & Share of excess winter mortality/deaths \\
\hline Presence of leak, damp, rot & Share of population with a leak, damp, or rot in their dwelling \\
\hline
\end{tabular}

Source: own elaboration based on [49].

In terms of research on fuel poverty, subjective indicators based on the opinions of respondents are also used, as already mentioned. Biernat-Jarka et al. [30] indicate that subjective measures were used in research by Gordon et al. [50], Healy and Clinch [51], Healy et al. [52], Petrova et al. [53], and Thomson and Snell [54].

Due to the multidimensionality of fuel poverty, composite measures are increasingly being used; these represent a compromise between the simplicity of one-dimensional indicators and the need to take into account the multidimensionality of the fuel poverty problem. They are an attempt to overcome the shortcomings and imperfections of onedimensional indicators, while at the same time providing a result that condenses the information into single, easily interpretable values [55]. The characteristics of selected multidimensional measures are included in Table 3.

Table 3. Multidimensional ways to measure fuel poverty—selected indicators.

\begin{tabular}{|c|c|c|}
\hline Authors & Description of the Indicator & \\
\hline Bossert, W. etc. [56] & $\begin{array}{l}\text { Individual multidimensional } \\
\text { poverty measures } \\
\text { Aggregate multidimensional } \\
\text { poverty measures }\end{array}$ & $\begin{array}{l}\text { Models and mathematical formulas serving as the basis for further } \\
\text { research on the multidimensionality of energy poverty and for } \\
\text { indicating possible solutions in the field of measurement }\end{array}$ \\
\hline $\begin{array}{l}\text { Nussbaumer, P. } \\
\text { etc. [57] }\end{array}$ & $\begin{array}{l}\text { Multidimensional energy } \\
\text { poverty index (MEPI) }\end{array}$ & $\begin{array}{l}\text { Multidimensional energy poverty index (MEPI), which considers } \\
\text { both the occurrence and intensity of energy poverty and is a new tool } \\
\text { supporting policy making in this area }\end{array}$ \\
\hline $\begin{array}{l}\text { Bouzarovski, S. } \\
\text { etc. [47] }\end{array}$ & $\begin{array}{l}\text { Energy poverty index }=(0.5 \mathrm{x} \% \\
\text { inability }+0.25 \mathrm{x} \% \text { arrears }+0.25 \\
\quad \mathrm{x} \% \text { Housing faults }) \times 100\end{array}$ & $\begin{array}{l}\text { Energy poverty index takes into account the EU-SILC population } \\
\text { percentages of people who have reported (i) being unable to keep } \\
\text { their homes adequately warm (Inability); (ii) having arrears in utility } \\
\text { bills (Arrears); and (iii) living in a home with a leaking roof, or the } \\
\text { presence of damp and rot (Housing faults) }\end{array}$ \\
\hline Alkire, S. etc. [58] & $\begin{array}{l}\text { Five dimensions of energy } \\
\text { deprivation-based on } \\
\text { Household Budget Survey }\end{array}$ & $\begin{array}{l}\text { Two objective indicators: "low income, high costs" and 'high share of } \\
\text { energy expenditure in income', as well as three subjective indicators: } \\
\text { "inability to keep the home adequately warm", "presence of leaks, } \\
\text { damp, or rot", and "difficulties paying utility bills" Households that } \\
\text { experience at least two forms of deprivation are } \\
\text { considered energy-poor. }\end{array}$ \\
\hline
\end{tabular}

Source: own elaboration based on [55].

The absence of access to affordable energy resources is undoubtedly a form of deprivation, resulting in various forms of social injustices [29]. Another approach to measurement 
is presented by [59], pointing to ways of operationalizing the issue of energy poverty measurement. Their presentation is shown in Figure 3.

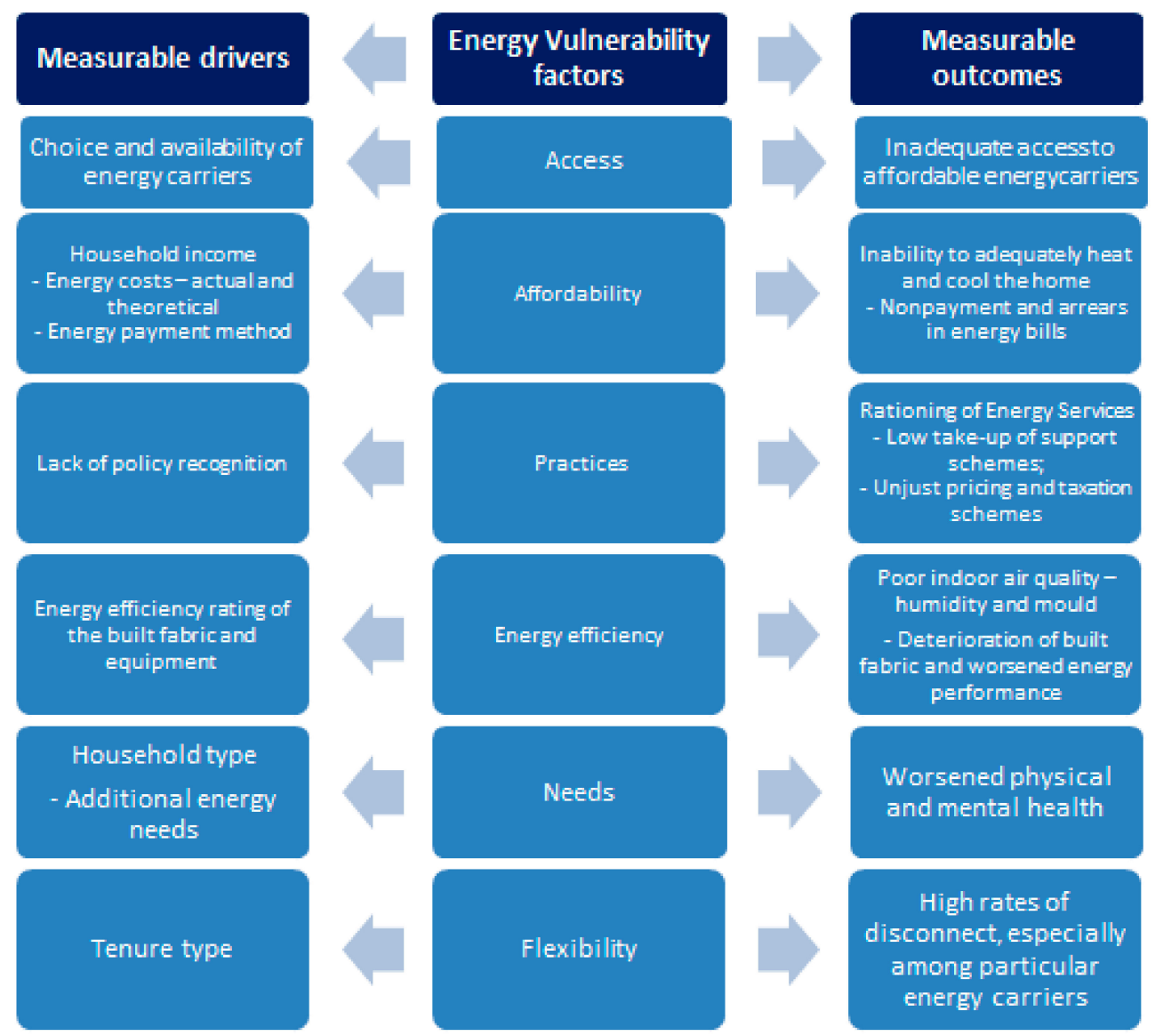

Figure 3. Arrangement of measurable drivers and outcomes by energy vulnerability factors. Source: [60].

In the view of Thomson et al. [59], three main measurement approaches can be identified:

- Expenditure approach — examination of the energy costs faced by households against absolute or relative thresholds providing a proxy for estimating the extent of domestic energy deprivation;

- Consensual approach-based on self-reported assessments of indoor housing conditions, and the ability to attain certain necessities relative to the society in which a household resides;

- Direct measurement-the level of energy services (such as heating) in the home is compared to a set standard.

Analysing the literature and various scientific studies and statistics, there is no single definition used to identify households in fuel poverty [60]. Various indicators are used for this purpose, most often those relating to energy-related expenditure. Research on energy poverty has great potential, especially currently, when the most developed EU countries are also affected by this problem. Nowadays, energy poverty is not only the inability to heat one's home; in an era of ubiquitous technological devices, energy poverty can result in exclusion and become a determinant of social inequality. Therefore, research on energy exclusion needs to cover a broader spectrum of areas and issues. A standard approach and standard measurement are not sufficient. The use of energy for communication, education, and access to e-commerce not only contributes to fuel poverty but is also associated with social exclusion, indicating another negative effect of this phenomenon. To this must be added elements related to the measurement and impact of environmental factors, natural factors, or weather conditions. The degree, state, and scope of poverty, in addition to 
the determinants already mentioned, will also be influenced by the state of housing in individual countries. People living in detached houses and elderly people on low incomes are more exposed to energy poverty, while energy losses in buildings that have not been thermally renovated may also create susceptibility. These elements are important in terms of considering, measuring, and addressing the causes and effects of energy poverty.

In conclusion, the measurement system is extremely complex, and energy poverty cannot be assessed by simple correlations or indicators. A multidimensional approach is needed. A further problem is the availability of data. However, while the measures offered and presented are not perfect, they can provide the foundation for further research and can be used for filling research gaps and assessing economic implications.

\subsection{Energy Poverty Alleviation Orientations for Energy Policy Development}

Today, energy policy is increasingly linked to the implementation of innovations to decarbonise energy, make energy use less costly and resource-intensive, and meet sustainability requirements. Energy poverty can result from various causes. These include technical, economic, and social determinants. It can affect households directly and citizens themselves, as well as the whole economy, contributing to social, economic, and health problems. The transition to green energy can reduce the vulnerability of a country and increase its resilience to energy poverty, thereby contributing to better development outcomes. In the early stages of renewable energy deployment, it is not cost-competitive; only in the long term can it contribute to development outcomes and sustainability utilisation. In the short term it can contribute to higher cost burdens for consumers and thus worsen sustainability outcomes [61].

\section{Results}

Analysing the data on access to electricity, in all European countries between 2011 and 2019, access was 100\%. However, when looking at the data in more detail, it is important to note that the share of people with access to clean cooking fuels is significantly lower in some countries. Having access to electricity means that a household can use it for basic purposes, such as lighting. However, it may not be able to pay for electricity for more energy-intensive purposes, such as cooking. In this situation, the household uses cheaper fuel, especially wood or coal, to cook. In most European countries, access to clean fuels for cooking is 100\%, while in Albania, Bosnia and Herzegovina, Montenegro, and the Ukraine it is much less- $46 \%$ to $95 \%$ of households use them. It should also be noted that access to clean energy is much lower in rural areas in these countries (Figure 4).

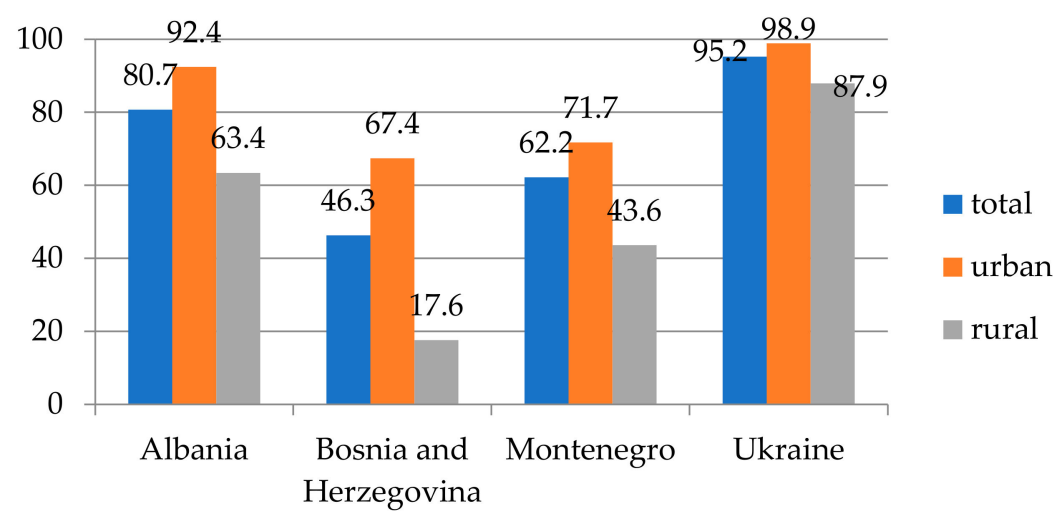

Figure 4. European countries with the lowest percentage of households using clean fuel for cooking in 2019 (total, urban, and rural areas). Source: own preparation based on Eurostat and World Bank database $[1,62]$.

The problem of maintaining an adequate (comfortable) temperature in the home significantly affects the level of energy poverty. When analysing the problem of inability to maintain adequate heat at home, it should be noted that, firstly, this problem has been 
gradually decreasing between 2011 and 2019, and secondly, very large differences between the studied countries are evident, especially between the countries of the so-called 'old EU', the 'new EU', and non-associated countries. In 2019, the highest percentages of people in the total population who were in a state of enforced inability to adequately heat their homes were in Kosovo (40.2\%), Albania (36.8\%), North Macedonia (33.1\%), Bulgaria (30.1\%), and Lithuania $(26.7 \%)$. The least affected countries were Switzerland ( $0.3 \%$ of the population), Norway (1\%), and Austria (1.8\%). The EU-27 average was $6.9 \%$. Figure 5 presents findings for the 'inability to stay warm enough at home' indicator in European countries for 2011, 2015, and 2019.

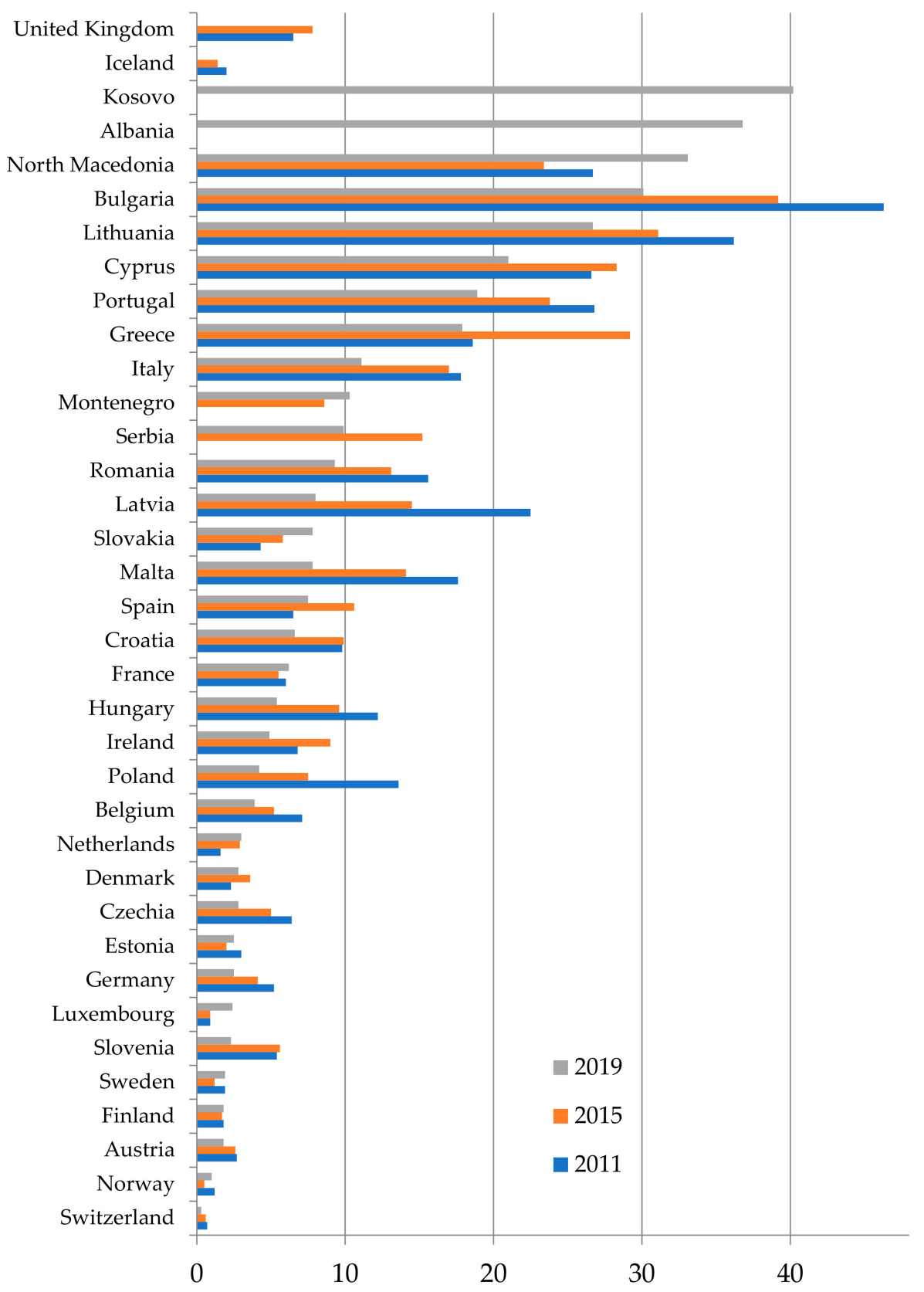

Figure 5. Inability to keep home adequately warm in European countries in 2011, 2015, 2019 \%. (2019, Iceland and UK there are no data; 2011, 2015, Kosovo, Albania no data; 2011, Serbia, Montenegro no data). Source: own preparation based on the Eurostat database [62]. 
It is also interesting to look at how this has changed over time across states. Table 4 presents the changes in the percentage of people having trouble maintaining an adequate temperature at home in 2019 compared to 2011.

Table 4. Change in the percentage of people who have problems maintaining an appropriate temperature at home: 2019 compared to $2011 \%$.

\begin{tabular}{|c|c|c|c|}
\hline $\begin{array}{l}\text { Country (Old UE + } \\
\text { Western Countries) }\end{array}$ & $\begin{array}{l}\text { Change } \\
2019 / 2011\end{array}$ & $\begin{array}{c}\text { Country (New UE }+ \\
\text { Non-Associated Countries) }\end{array}$ & $\begin{array}{l}\text { Change } \\
\text { 2019/2011 }\end{array}$ \\
\hline Germany & $-51.92 \%$ & Poland & $-69.12 \%$ \\
\hline Belgium & $-45.07 \%$ & Latvia & $-64.44 \%$ \\
\hline Italy & $-37.64 \%$ & Slovenia & $-57.41 \%$ \\
\hline Austria & $-33.33 \%$ & Czech Republic & $-56.25 \%$ \\
\hline Portugal & $-29.48 \%$ & Hungary & $-55.74 \%$ \\
\hline Ireland & $-27.94 \%$ & Malta & $-55.68 \%$ \\
\hline Greece & $-3.76 \%$ & Romania & $-40.38 \%$ \\
\hline Finland & $0.00 \%$ & Bulgaria & $-34.99 \%$ \\
\hline Sweden & $0.00 \%$ & Croatia & $-32.65 \%$ \\
\hline France & $3.33 \%$ & Lithuania & $-26.24 \%$ \\
\hline Spain & $15.38 \%$ & Cyprus & $-21.05 \%$ \\
\hline $\mathrm{UK}^{* *}$ & $20.00 \%$ & Estonia & $-16.67 \%$ \\
\hline Denmark & $21.74 \%$ & Slovakia & $81.40 \%$ \\
\hline Netherlands & $87.50 \%$ & Serbia & -0.34868 \\
\hline Luxembourg & $166.67 \%$ & Montenegro * & $19.77 \%$ \\
\hline Switzerland & $-57.14 \%$ & North Macedonia & $23.97 \%$ \\
\hline Iceland ** & $-30.00 \%$ & Albania & . \\
\hline Norway & $-16.67 \%$ & Kosovo & . \\
\hline
\end{tabular}

* due to lack of data, comparing 2019 to $2015 .{ }^{* *}$ due to lack of data, comparing 2018 to 2011. Source: Authors calculations.

Analysing the changes in the problem of maintaining an adequate home temperature, differences are observed between the so-called old EU countries, the new EU countries, and non-EU countries. In 2019 compared to 2011, the percentage of people with this problem decreased more in the so-called new EU countries compared to the so-called old EU countries. This could mean that the common energy policy contributed to member countries gaining more.

An important factor affecting the level of energy poverty is electricity prices. Their levels in 2019 are presented in Table 5.

An analysis of the data presented in Table 6 provided some interesting findings. In 2019, the lowest electricity prices were in countries characterized by the highest percentage of people affected by the problem of not being able to maintain adequate heat at home, as well as having difficulty accessing clean energy for cooking. Therefore, to better illustrate the factors influencing the problem of energy poverty, in addition to the price, attention was also paid to the share of household expenditure on electricity, gas, and other fuels (Figure 6). A household is said to be energy-poor if it spends more than $10 \%$ of its income on fuel to keep warm. Therefore, the share of household expenditure spent on energy is another important indicator that has been highlighted in the study of energy poverty. 
Table 5. Average electricity prices for household consumers in 2019 (in EUR per kWh, without taxes).

\begin{tabular}{cccccc}
\hline Country & Price & Country & Price & Country & Price \\
\hline Ukraine & 0.0406 & Romania & 0.1025 & Norway & 0.1264 \\
Kosovo & 0.0528 & Estonia & 0.1027 & Spain & 0.1287 \\
Serbia & 0.0551 & Croatia & 0.103 & Sweden & 0.1316 \\
North & 0.0669 & Denmark & 0.1042 & Germany & 0.1321 \\
Macedonia & 0.0728 & Iceland & 0.1132 & Luxembourg & 0.1325 \\
B IH & 0.0778 & Latvia & 0.1144 & Austria & 0.1349 \\
Albania & 0.0798 & Slovenia & 0.1146 & Netherlands & 0.1359 \\
Bulgaria & Greece & 0.1189 & Italy & 0.1427 \\
Montenegro & 0.0847 & Finland & 0.1201 & UK & 0.1512 \\
Hungary & 0.0864 & Portugal & 0.1204 & Cyprus & 0.1576 \\
Poland & 0.0867 & Malta & 0.1227 & Liechtenstein & 0.1765 \\
Lithuania & 0.0947 & Czechia & 0.1255 & Belgium & 0.1954 \\
Slovakia & 0.0969 & France & 0.126 & Ireland & 0.2130 \\
Moldova & 0.1019 & & &
\end{tabular}

Source: own preparation based on the Eurostat database [62].

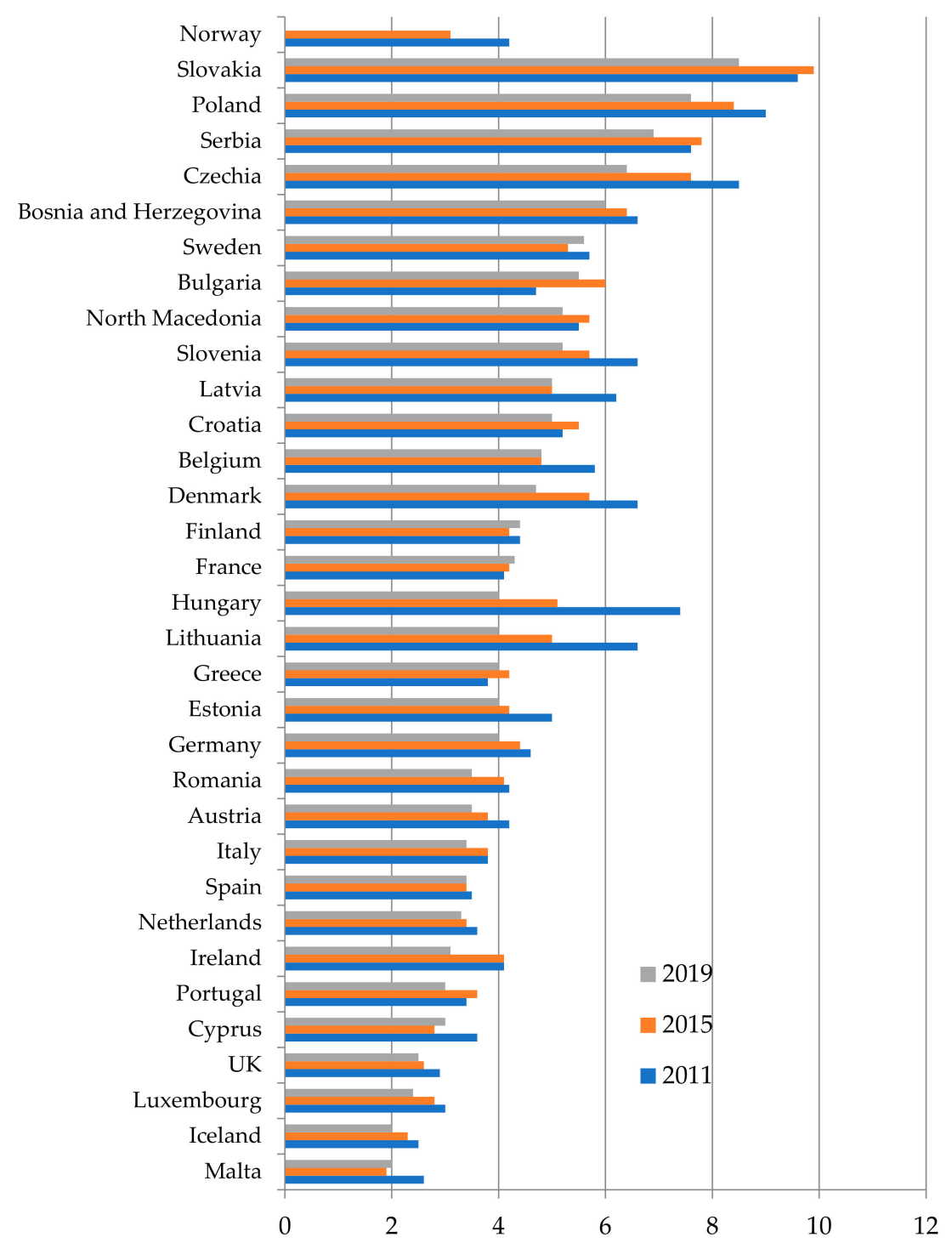

Figure 6. Electricity, gas, and other fuel expenditure of households in European countries in 2011, 2015, 2019 (in \%). (2019, Norway there are no data; 2011, 2015, 2019, Kosovo, Albania, Montenegro there are no data). Source: own preparation based on Eurostat database [62]. 
The highest share of expenditure on electricity, gas, and other fuels in total consumption expenditure is in Slovakia (8.5\%), Poland (7.6\%), and Serbia (6.9\%). The least burdened in this respect are Malta (2\%), Iceland (2\%), and Luxembourg (2.4\%). It should also be noted that, unfortunately, there are no data available on this issue for countries such as Kosovo, Albania, and Montenegro. However, it can be assumed that since there are problems with heating the home or access to clean energy for cooking, spending on these categories of goods can be quite a burden on household budgets in these countries.

High energy costs and/or low household incomes often force people in fuel poverty to default on their utility bills. It is therefore important to indicate the percentage of people in the total population who are in arrears with utility bills.

Table 6. Percentage of persons from the total population who are in arrears on utility bills in 2019 in European countries.

\begin{tabular}{cccccc}
\hline Country & $\mathbf{\%}$ & Country & $\mathbf{\%}$ & Country & $\mathbf{\%}$ \\
\hline Netherlands & 1.5 & Switzerland & 4.5 & Cyprus & 10.4 \\
Czechia & 1.8 & UK & 5 & Slovenia & 11.2 \\
Germany & 2.2 & France & 5.6 & Romania & 13.7 \\
Sweden & 2.3 & Poland & 5.8 & Croatia & 14.8 \\
Luxembourg & 2.4 & Spain & 6.5 & Serbia & 25.8 \\
Austria & 2.4 & Malta & 6.5 & Albania & 26.5 \\
Norway & 3.2 & Estonia & 7.2 & Turkey & 26.6 \\
Denmark & 3.6 & Lithuania & 7.5 & Bulgaria & 27.6 \\
Iceland & 4 & Finland & 7.8 & Greece & 32.5 \\
Belgium & 4.1 & Slovakia & 8.4 & Montenegro & 32.9 \\
Portugal & 4.3 & Latvia & 8.7 & North Macedonia & 34.4 \\
Italy & 4.5 & Ireland & 8.9 & Kosovo & 49 \\
& \multicolumn{7}{c}{} & \\
\hline
\end{tabular}

Source: own preparation based on Eurostat database [62].

In 2019, Kosovo, North Macedonia, and Montenegro-the countries with the highest percentage of people affected by the problem of keeping their homes warm-also had the highest percentage of people in arrears with utility payments. In contrast, in countries such as the Netherlands, the Czech Republic, Germany, and Sweden, paying utility bills is a problem for only a small percentage of the total population.

An important indicator, both from the perspective of energy poverty and sustainable development, is the share of renewable energy in gross energy consumption. This indicator measures the extent to which renewable energy has replaced fossil and/or nuclear fuels and therefore contributes to the decarbonisation of economies. The share of renewable energy in the final gross energy consumption is presented in Figure 7 and in Table 7.

The highest share of renewable energy in gross final energy consumption occurred in Scandinavian countries: Iceland (78\% in 2019), Norway (74\%), and Sweden (56\%). By contrast, the lowest use of this energy was found in countries such as Luxembourg (7\%), Malta $(8 \%)$, and the The Netherlands (8\%).

It is of interest that in Albania and Kosovo, countries with a quite high percentage of households that had problems maintaining an adequate home temperature, the share of renewable energy use (36.6\% and $25.6 \%$, respectively) was higher than the EU27 average $(19.7 \%)$.

Analysing the changes between 2011 and 2019, in most of the countries belonging to the so-called new EU, the increase in the share of renewable energy in total energy has been slower than in most of the countries of the so-called old EU. This may be affected by the different goals of the economic policies pursued by these countries. Moreover, households' goals may also be different and not necessarily related to investment in this area. 


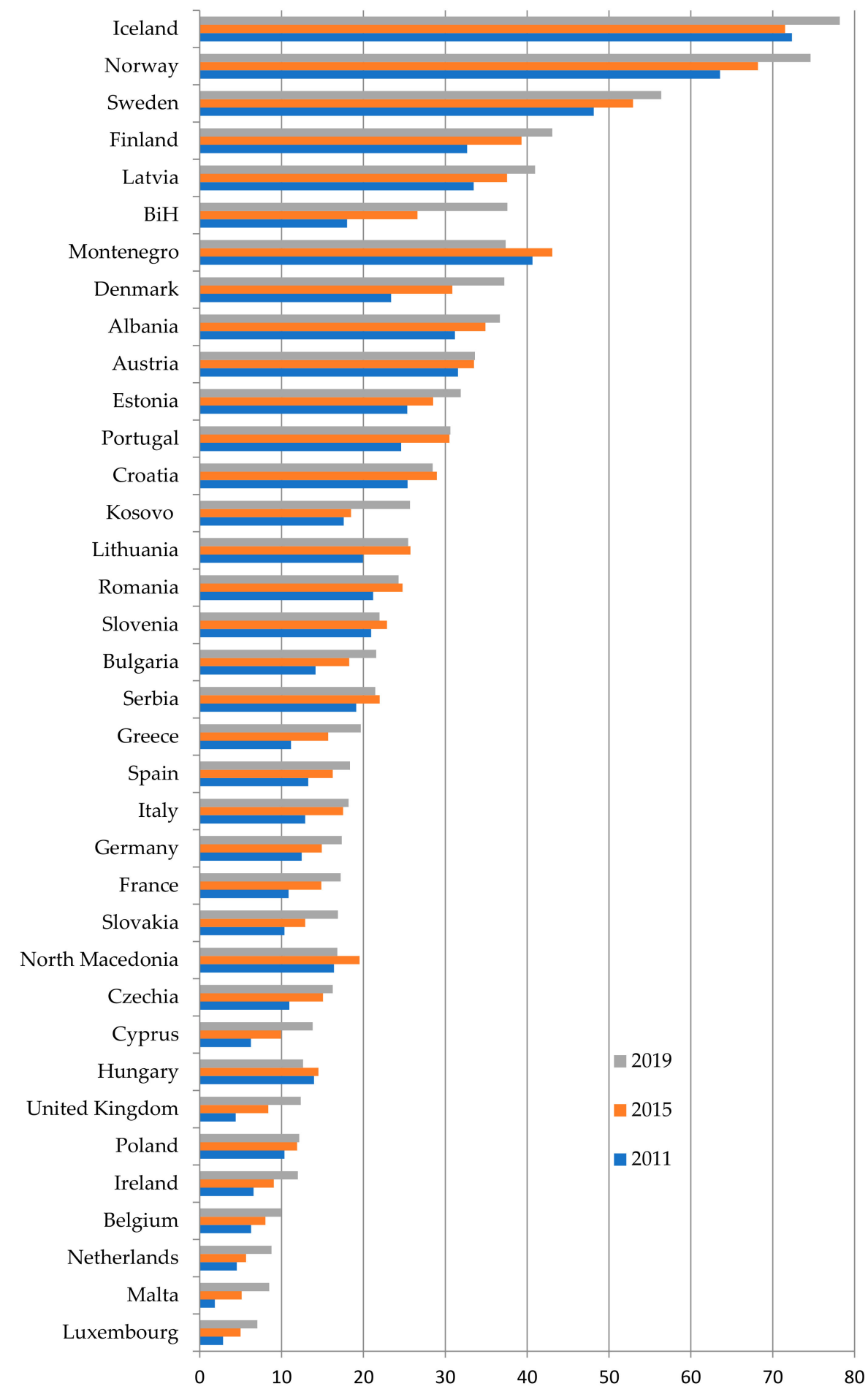

Figure 7. Share of renewable energy in final gross energy consumption in European countries in 2011, 2015, 2019 (in \%). Source: own preparation based on Eurostat database [62]. 
Table 7. Change in the share of renewable energy in gross final energy consumption 2019 compared to $2011 \%$.

\begin{tabular}{cccc}
\hline $\begin{array}{c}\text { Country (Old UE + } \\
\text { Western Countries) }\end{array}$ & $\begin{array}{c}\text { Change } \\
\mathbf{2 0 1 9 / 2 0 1 1}\end{array}$ & $\begin{array}{c}\text { Country (New UE + } \\
\text { Non-Associated Countries }\end{array}$ & $\begin{array}{c}\text { Change } \\
\mathbf{2 0 1 9} \mathbf{2 0 1 1}\end{array}$ \\
\hline UK & $180.87 \%$ & Malta & $358.81 \%$ \\
Luxembourg & $146.74 \%$ & Slovakia & $63.26 \%$ \\
Cyprus & $120.41 \%$ & Czechia & $48.41 \%$ \\
Netherlands & $93.81 \%$ & Lithuania & $27.66 \%$ \\
Ireland & $82.40 \%$ & Estonia & $25.81 \%$ \\
Greece & $76.43 \%$ & Portugal & $24.43 \%$ \\
Denmark & $59.06 \%$ & Latvia & $22.39 \%$ \\
France & $58.54 \%$ & Poland & $17.48 \%$ \\
Belgium & $58.15 \%$ & Romania & $14.65 \%$ \\
Bulgaria & $52.37 \%$ & Croatia & $12.12 \%$ \\
Italy & $41.15 \%$ & Slovenia & $4.96 \%$ \\
Germany & $39.36 \%$ & Hungary & $-9.72 \%$ \\
Spain & $38.61 \%$ & BiH & $108.82 \%$ \\
Finland & $31.89 \%$ & Kosovo & $45.96 \%$ \\
Sweden & $17.15 \%$ & Albania & $17.57 \%$ \\
Norway & $17.41 \%$ & Serbia & $12.16 \%$ \\
Iceland & $8.07 \%$ & North Macedonia & $2.45 \%$ \\
Montenegro & $-8.06 \%$ \\
\hline
\end{tabular}

Switzerland no data available. Source: Authors calculations.

To answer in more detail the research questions posed in the paper, for most of the analysed countries an analysis of relationships was conducted using the Statistica program, considering:

- The level of inability to adequately heat the home (which is one of the indicators of energy poverty) and the level of GDP per capita (RQ1);

- The correlation between the level of inability to heat the home and the household expenditure on electricity, gas, and other fuels (RQ1);

- The correlation between household expenditure on electricity, gas, and other fuel and the level of GDP (QR1);

- $\quad$ The correlation between GDP per capita and the share of renewable energy in gross energy consumption (RQ2);

- The correlation between the inability to heat the home and the share of renewable energy in gross energy consumption (which is one of the indicators of sustainable development, in terms of environmental governance) (RQ2);

- The correlation between household expenditure on electricity, gas, and other fuels and the share of renewable energy in gross energy consumption (RQ2).

Unfortunately, due to the absence or incompleteness of data for the countries most vulnerable to energy poverty (Albania, Kosovo, Montenegro, and North Macedonia), a dependency analysis could not be fully conducted in these countries. The results of the analyses are presented in Table 8.

(RQ1) The results of the analysis carried out show that, in most of the countries studied, there was a statistically significant, strong negative correlation between the level of GDP per capita and the poverty rate (represented by the level of inability to maintain adequate heat at home). The higher the income level of the population, the smaller this problem became. Weak correlations in this regard occurred in Finland, France, Italy, The Netherlands, Spain, the UK, and Estonia. By contrast, no relationship between these characteristics was found in Denmark or Norway. In the country most exposed to energy poverty, North Macedonia, there was no such relationship either, which is probably related to the low (but growing) level of GDP per capita. This still translates into a low income for the population and consequent difficulties in the payment of basic charges (leading to arrears on utility bills), as shown in Table 7. North Macedonia is the country with one of the highest percentages of people with this type of problem. 
Table 8. Correlation analysis.

\begin{tabular}{|c|c|c|c|c|c|c|c|}
\hline & Variable & Mean & St. Dev. & Var.1 & Var.2 & Var.3 & Var.4 \\
\hline \multirow[t]{4}{*}{ Austria } & Var.1 & 33.11 & 0.701 & 1.000000 & 0.448180 & -0.406419 & -0.765819 \\
\hline & Var.2 & $53,719.02$ & 1130.371 & 0.448180 & 1.000000 & -0.880358 & -0.775614 \\
\hline & Var.3 & 2.54 & 0.548 & -0.406419 & -0.880358 & 1.000000 & 0.800675 \\
\hline & Var.4 & 3.87 & 0.292 & -0.765819 & -0.775614 & 0.800675 & 1.000000 \\
\hline \multirow[t]{4}{*}{ Belgium } & Var.1 & 8.26 & 1.173 & 1.000000 & 0.940091 & -0.862964 & -0.759961 \\
\hline & Var.2 & $49,543.96$ & 1338.292 & 0.940091 & 1.000000 & -0.779414 & -0.734775 \\
\hline & Var.3 & 5.53 & 0.947 & -0.862964 & -0.779414 & 1.000000 & 0.755346 \\
\hline & Var.4 & 5.22 & 0.572 & -0.759961 & -0.734775 & 0.755346 & 1.000000 \\
\hline \multirow[t]{4}{*}{ Denmark } & Var.1 & 30.62 & 4.708 & 1.000000 & 0.953404 & 0.119047 & -0.974226 \\
\hline & Var.2 & $53,603.43$ & 2388.961 & 0.953404 & 1.000000 & -0.072173 & -0.958482 \\
\hline & Var.3 & 2.92 & 0.489 & 0.119047 & -0.072173 & 1.000000 & 0.074675 \\
\hline & Var.4 & 5.72 & 0.703 & -0.974226 & -0.958482 & 0.074675 & 1.000000 \\
\hline \multirow[t]{4}{*}{ Germany } & Var.1 & 27.85 & 2.368 & 1.000000 & 0.951391 & -0.969505 & -0.893504 \\
\hline & Var.2 & $51,453.05$ & 1586.315 & 0.951391 & 1.000000 & -0.970632 & -0.911358 \\
\hline & Var.3 & 4.04 & 1.057 & -0.969505 & -0.970632 & 1.000000 & 0.906499 \\
\hline & Var.4 & 4.41 & 0.379 & -0.893504 & -0.911358 & 0.906499 & 1.000000 \\
\hline \multirow[t]{4}{*}{ Greece } & Var.1 & 15.78 & 2.4647 & 1.000000 & -0.088318 & -0.091306 & 0.141654 \\
\hline & Var. 2 & $28,746.41$ & 840.5285 & -0.088318 & 1.000000 & -0.919990 & -0.648848 \\
\hline & Var.3 & 25.74 & 5.1294 & -0.091306 & -0.919990 & 1.000000 & 0.474966 \\
\hline & Var.4 & 4.18 & 0.2108 & 0.141654 & -0.648848 & 0.474966 & 1.000000 \\
\hline \multirow[t]{4}{*}{ France } & Var.1 & 14.71 & 1.903 & 1.000000 & 0.827994 & -0.419090 & -0.094425 \\
\hline & Var.2 & $43,800.71$ & 1147.488 & 0.827994 & 1.000000 & -0.375521 & -0.318985 \\
\hline & Var.3 & 5.68 & 0.606 & -0.419090 & -0.375521 & 1.000000 & 0.497100 \\
\hline & Var.4 & 4.29 & 0.190 & -0.094425 & -0.318985 & 0.497100 & 1.000000 \\
\hline \multirow[t]{4}{*}{ Finland } & Var.1 & 38.45 & 3.343 & 1.000000 & 0.485617 & 0.364521 & -0.409562 \\
\hline & Var.2 & $46,528.05$ & 1360.644 & 0.485617 & 1.000000 & 0.633295 & 0.072400 \\
\hline & Var.3 & 1.66 & 0.230 & 0.364521 & 0.633295 & 1.000000 & -0.437998 \\
\hline & Var.4 & 4.40 & 0.112 & -0.409562 & 0.072400 & -0.437998 & 1.000000 \\
\hline \multirow[t]{4}{*}{ Luxemburg } & Var.1s & 5.2 & 1.999 & 1.000000 & 0.869695 & 0.761947 & -0.806236 \\
\hline & Var.2 & $110,138.8$ & 3287.483 & 0.869695 & 1.000000 & 0.775171 & -0.940717 \\
\hline & Var.3 & 1.4 & 0.675 & 0.761947 & 0.775171 & 1.000000 & -0.687445 \\
\hline & Var.4 & 2.7 & 0.302 & -0.806236 & -0.940717 & -0.687445 & 1.000000 \\
\hline \multirow[t]{4}{*}{ Ireland } & Var.1 & 9.03 & 1.83 & 1.000000 & 0.963581 & -0.707009 & -0.884507 \\
\hline & Var.2 & $68,402.38$ & 13730.34 & 0.963581 & 1.000000 & -0.779755 & -0.901820 \\
\hline & Var.3 & 6.97 & 2.17 & -0.707009 & -0.779755 & 1.000000 & 0.918795 \\
\hline & Var.4 & 3.80 & 0.53 & -0.884507 & -0.901820 & 0.918795 & 1.000000 \\
\hline \multirow[t]{4}{*}{ Italy } & Var.1 & 16.81 & 1.705 & 1.000000 & -0.328209 & -0.573031 & -0.523150 \\
\hline & Var.2 & $41,326.94$ & 1085.190 & -0.328209 & 1.000000 & -0.443815 & -0.326900 \\
\hline & Var.3 & 16.60 & 2.941 & -0.573031 & -0.443815 & 1.000000 & 0.843202 \\
\hline & Var.4 & 3.70 & 0.332 & -0.523150 & -0.326900 & 0.843202 & 1.000000 \\
\hline \multirow[t]{4}{*}{ Netherland } & Var.1 & 5.92 & 1.405 & 1.000000 & 0.944043 & 0.384217 & -0.668676 \\
\hline & Var.2 & $53,653.55$ & 1862.520 & 0.944043 & 1.000000 & 0.136906 & -0.781530 \\
\hline & Var.3 & 2.49 & 0.446 & 0.384217 & 0.136906 & 1.000000 & -0.016353 \\
\hline & Var.4 & 3.49 & 0.362 & -0.668676 & -0.781530 & -0.016353 & 1.000000 \\
\hline \multirow[t]{4}{*}{ Portugal } & Var.1 & 28.58 & 2.758 & 1.000000 & 0.612593 & -0.716282 & -0.561154 \\
\hline & Var.2 & $31,875.61$ & 1744.269 & 0.612593 & 1.000000 & -0.941661 & -0.949609 \\
\hline & Var.3 & 23.89 & 3.756 & -0.716282 & -0.941661 & 1.000000 & 0.925349 \\
\hline & Var.4 & 3.38 & 0.315 & -0.561154 & -0.949609 & 0.925349 & 1.000000 \\
\hline \multirow[t]{4}{*}{ Spain } & Var.1 & 16.24 & 1.681 & 1.000000 & 0.784627 & 0.241497 & -0.656266 \\
\hline & Var.2 & $37,832.90$ & 2036.478 & 0.784627 & 1.000000 & -0.210046 & -0.752576 \\
\hline & Var.3 & 8.89 & 1.524 & 0.241497 & -0.210046 & 1.000000 & -0.072595 \\
\hline & Var.4 & 3.47 & 0.173 & -0.656266 & -0.752576 & -0.072595 & 1.000000 \\
\hline \multirow[t]{4}{*}{ Sweden } & Var.1 & 52.47 & 2.548 & 1.000000 & 0.908306 & 0.355763 & -0.465640 \\
\hline & Var.2 & $50,451.25$ & 1711.748 & 0.908306 & 1.000000 & 0.599164 & -0.539882 \\
\hline & Var.3 & 1.74 & 0.575 & 0.355763 & 0.599164 & 1.000000 & -0.148719 \\
\hline & Var.4 & 5.57 & 0.229 & -0.465640 & -0.539882 & -0.148719 & 1.000000 \\
\hline \multirow[t]{4}{*}{ UK } & Var.1 & 7.98 & 2.885 & 1.000000 & 0.986670 & -0.669881 & -0.855661 \\
\hline & Var.2 & $44,510.13$ & 1517.602 & 0.986670 & 1.000000 & -0.607872 & -0.877974 \\
\hline & Var.3 & 7.24 & 1.851 & -0.669881 & -0.607872 & 1.000000 & 0.735644 \\
\hline & Var.4 & 2.72 & 0.282 & -0.855661 & -0.877974 & 0.735644 & 1.000000 \\
\hline
\end{tabular}


Table 8. Cont.

\begin{tabular}{|c|c|c|c|c|c|c|c|}
\hline & Variable & Mean & St. Dev. & Var.1 & Var.2 & Var.3 & Var.4 \\
\hline \multirow[t]{4}{*}{ Iceland } & Var.1 & 74.21 & 2.095 & 1.000000 & 0.697710 & -0.689326 & -0.681932 \\
\hline & Var.2 & $52,592.12$ & 3475.382 & 0.697710 & 1.000000 & -0.794465 & -0.976711 \\
\hline & Var.3 & 1.43 & 0.339 & -0.689326 & -0.794465 & 1.000000 & 0.693418 \\
\hline & Var.4 & 2.26 & 0.188 & -0.681932 & -0.976711 & 0.693418 & 1.000000 \\
\hline \multirow[t]{4}{*}{ Norway } & Var.1 & 68.47 & 3.566 & 1.000000 & 0.956943 & -0.014130 & -0.089413 \\
\hline & Var.2 & $62,928.16$ & 1173.755 & 0.956943 & 1.000000 & -0.083313 & -0.126524 \\
\hline & Var.3 & 0.83 & 0.212 & -0.014130 & -0.083313 & 1.000000 & 0.913143 \\
\hline & Var.4 & 3.58 & 0.353 & -0.089413 & -0.126524 & 0.913143 & 1.000000 \\
\hline \multirow[t]{4}{*}{ Switzerland } & Var.1 & $68,302.08$ & 1695.683 & - & 1.000000 & -0.271892 & - \\
\hline & Var.2 & - & - & - & - & - & - \\
\hline & Var.3 & 0.52 & 0.148 & - & -0.271892 & 1.000000 & - \\
\hline & Var.4 & - & - & - & - & - & - \\
\hline \multirow[t]{4}{*}{ Bulgaria } & Var.1 & 17.54 & 29.347 & 1.000000 & -0.958628 & 0.953977 & 0.999436 \\
\hline & Var.2 & $17,441.53$ & 6292.492 & -0.958628 & 1.000000 & -0.997112 & -0.966873 \\
\hline & Var.3 & 45.79 & 20.120 & 0.953977 & -0.997112 & 1.000000 & 0.961745 \\
\hline & Var.4 & 14.81 & 30.288 & 0.999436 & -0.966873 & 0.961745 & 1.000000 \\
\hline \multirow[t]{4}{*}{ Czechia } & Var.1 & 8.2611 & 1.173003 & 1.000000 & 0.988279 & -0.923096 & -0.896258 \\
\hline & Var.2 & 106.0000 & 2.738613 & 0.988279 & 1.000000 & -0.957501 & -0.941204 \\
\hline & Var.3 & 4.7556 & 1.663664 & -0.923096 & -0.957501 & 1.000000 & 0.925814 \\
\hline & Var.4 & 7.7111 & 0.902004 & -0.896258 & -0.941204 & 0.925814 & 1.000000 \\
\hline \multirow[t]{4}{*}{ Cyprus } & Var.1 & 9.89 & 2.623 & 1.000000 & 0.613993 & -0.796003 & -0.642159 \\
\hline & Var.2 & $36,531.00$ & 2539.671 & 0.613993 & 1.000000 & -0.848893 & -0.329384 \\
\hline & Var.3 & 25.97 & 3.615 & -0.796003 & -0.848893 & 1.000000 & 0.711218 \\
\hline & Var.4 & 3.23 & 0.577 & -0.642159 & -0.329384 & 0.711218 & 1.000000 \\
\hline \multirow[t]{4}{*}{ Croatia } & Var.1 & 27.67 & 1.070 & 1.000000 & 0.317315 & -0.254738 & 0.237731 \\
\hline & Var. 2 & $25,465.42$ & 1892.841 & 0.317315 & 1.000000 & -0.961969 & -0.809405 \\
\hline & Var.3 & 8.94 & 1.335 & -0.254738 & -0.961969 & 1.000000 & 0.778260 \\
\hline & Var.4 & 5.31 & 0.203 & 0.237731 & -0.809405 & 0.778260 & 1.000000 \\
\hline \multirow[t]{4}{*}{ Hungary } & Var.1 & 14.21 & 1.217 & 1.000000 & -0.854973 & 0.915524 & 0.710497 \\
\hline & Var.2 & $27,802.13$ & 2782.855 & -0.854973 & 1.000000 & -0.954069 & -0.915686 \\
\hline & Var.3 & 10.06 & 3.552 & 0.915524 & -0.954069 & 1.000000 & 0.902365 \\
\hline & Var.4 & 5.53 & 1.259 & 0.710497 & -0.915686 & 0.902365 & 1.000000 \\
\hline \multirow[t]{4}{*}{ Estonia } & Var.1 & 27.85 & 2.368 & 1.000000 & 0.958956 & -0.362217 & -0.910284 \\
\hline & Var.2 & $31,856.68$ & 2917.486 & 0.958956 & 1.000000 & -0.347527 & -0.862706 \\
\hline & Var.3 & 2.69 & 0.717 & -0.362217 & -0.347527 & 1.000000 & 0.628778 \\
\hline & Var.4 & 4.50 & 0.474 & -0.910284 & -0.862706 & 0.628778 & 1.000000 \\
\hline \multirow[t]{4}{*}{ Latvia } & Var.1 & 37.73 & 2.273 & 1.000000 & 0.907828 & -0.835574 & -0.759510 \\
\hline & Var.2 & $26,754.93$ & 2740.726 & 0.907828 & 1.000000 & -0.966007 & -0.679901 \\
\hline & Var.3 & 14.51 & 5.826 & -0.835574 & -0.966007 & 1.000000 & 0.658173 \\
\hline & Var.4 & 5.24 & 0.602 & -0.759510 & -0.679901 & 0.658173 & 1.000000 \\
\hline \multirow[t]{4}{*}{ Lithuania } & Var.1 & 23.91 & 2.158 & 1.000000 & 0.813340 & -0.721315 & -0.885198 \\
\hline & Var.2 & $31,185.58$ & 3716.437 & 0.813340 & 1.000000 & -0.753014 & -0.973349 \\
\hline & Var.3 & 29.99 & 3.285 & -0.721315 & -0.753014 & 1.000000 & 0.681757 \\
\hline & Var.4 & 5.31 & 0.992 & -0.885198 & -0.973349 & 0.681757 & 1.000000 \\
\hline \multirow[t]{4}{*}{ Malta } & Var.1 & 5.36 & 2.300 & 1.000000 & 0.986895 & -0.811429 & 0.472958 \\
\hline & Var.2 & $38,846.54$ & 4173.063 & 0.986895 & 1.000000 & -0.857213 & 0.419142 \\
\hline & Var.3 & 14.26 & 7.402 & -0.811429 & -0.857213 & 1.000000 & -0.297577 \\
\hline & Var.4 & 4.13 & 5.958 & 0.472958 & 0.419142 & -0.297577 & 1.000000 \\
\hline \multirow[t]{4}{*}{ Poland } & Var.1 & 11.38 & 0.528 & 1.000000 & 0.597227 & -0.709081 & -0.512291 \\
\hline & Var.2 & $28,258.81$ & 2860.623 & 0.597227 & 1.000000 & -0.938215 & -0.949494 \\
\hline & Var.3 & 8.57 & 3.464 & -0.709081 & -0.938215 & 1.000000 & 0.918916 \\
\hline & Var.4 & 8.40 & 0.543 & -0.512291 & -0.949494 & 0.918916 & 1.000000 \\
\hline \multirow[t]{4}{*}{ Romania } & Var.1 & 23.91 & 1.222 & 1.000000 & 0.500090 & -0.473355 & -0.147069 \\
\hline & Var.2 & $24,659.00$ & 3234.040 & 0.500090 & 1.000000 & -0.961092 & -0.670833 \\
\hline & Var.3 & 12.81 & 2.295 & -0.473355 & -0.961092 & 1.000000 & 0.583492 \\
\hline & Var.4 & 3.93 & 0.412 & -0.147069 & -0.670833 & 0.583492 & 1.000000 \\
\hline
\end{tabular}


Table 8. Cont.

\begin{tabular}{|c|c|c|c|c|c|c|c|}
\hline & Variable & Mean & St. Dev. & Var.1 & Var.2 & Var.3 & Var.4 \\
\hline \multirow[t]{4}{*}{ Slovakia } & Var.1 & 11.98 & 2.053 & 1.000000 & 0.761292 & 0.804289 & -0.527886 \\
\hline & Var.2 & $28,640.54$ & 2096.365 & 0.761292 & 1.000000 & 0.344012 & -0.863674 \\
\hline & Var.3 & 5.46 & 1.076 & 0.804289 & 0.344012 & 1.000000 & -0.044711 \\
\hline & Var.4 & 9.44 & 0.707 & -0.527886 & -0.863674 & -0.044711 & 1.000000 \\
\hline \multirow[t]{4}{*}{ Slovenia } & Var.1 & 22.00 & 0.722 & 1.000000 & -0.359217 & 0.175540 & 0.022844 \\
\hline & Var.2 & $34,841.45$ & 2410.816 & -0.359217 & 1.000000 & -0.933973 & -0.865702 \\
\hline & Var.3 & 4.66 & 1.248 & 0.175540 & -0.933973 & 1.000000 & 0.775669 \\
\hline & Var.4 & 5.89 & 0.595 & 0.022844 & -0.865702 & 0.775669 & 1.000000 \\
\hline \multirow{4}{*}{$\begin{array}{c}\text { North } \\
\text { Macedonia }\end{array}$} & Var.1 & 18.31 & 1.161 & 1.000000 & 0.019741 & -0.672407 & 0.562915 \\
\hline & Var.2 & $14,979.36$ & 1066.282 & 0.019741 & 1.000000 & 0.257983 & -0.549083 \\
\hline & Var.3 & 26.34 & 2.800 & -0.672407 & 0.257983 & 1.000000 & -0.375115 \\
\hline & Var.4 & 5.63 & 0.312 & 0.562915 & -0.549083 & -0.375115 & 1.000000 \\
\hline \multirow[t]{4}{*}{ Serbia } & Var.1 & 21.01 & 1.074 & 1.000000 & -0.004242 & - & 0.386609 \\
\hline & Var.2 & $16,062.35$ & 1186.077 & -0.004242 & 1.000000 & - & -0.601421 \\
\hline & Var.3 & - & - & - & - & - & - \\
\hline & Var.4 & 7.66 & 0.224 & 0.386609 & -0.601421 & - & 1.000000 \\
\hline \multirow[t]{4}{*}{$\mathrm{BiH}$} & Var.1 & 25.44 & 7.185 & 1.000000 & 0.902892 & - & -0.870812 \\
\hline & Var.2 & $12,787.65$ & 1356.126 & 0.902892 & 1.000000 & - & -0.945944 \\
\hline & Var.3 & - & - & - & - & - & - \\
\hline & Var.4 & 6.34 & 0.201 & -0.870812 & -0.945944 & - & 1.000000 \\
\hline
\end{tabular}

- There is no data. Var.1: Share of renewable energy in gross final energy consumption (\%). Var.2: GDP per capita PPP, international \$. Var.3: Inability to keep home adequately warm (\%). Var.4: Electricity, gas, and other fuel expenditure of households in European countries in 2011, 2015, 2019 (\%). The determined correlation coefficients are significant with $p<0.05000$. The strongest relationships are marked in bold. Source: Authors calculations.

(RQ1) In most of the countries analysed, there was a statistically significant positive correlation between the share of household spending on electricity, gas, and other fuels and the level of inability to heat the home. The greater the share of the budget accounted for by energy expenditure, the greater the problem of maintaining an adequate temperature in the place of residence. Weak correlations between these characteristics were found in Greece, France, Sweden, Estonia, Latvia, and Romania. No relationship was found in Denmark, the Netherlands, Spain, and Sweden.

(RQ1) There was a statistically significant negative relationship between the increase in income, represented by GDP per capita, and household spending on electricity, gas, and other fuels in most of the analysed countries. The share of these expenditures in total consumer spending decreased with increasing wealth. The weakest relationship between these characteristics was found in Greece, France, Italy, Sweden, Norway, Cyprus, North Macedonia, and Serbia.

(RQ2) A statistically significant positive relationship was observed in most countries between GDP per capita and the share of renewable energy in gross energy consumption, one of the indicators of sustainable development, in terms of environmental governance, This means that as the wealth of a country increased, renewable energy was used more and more. A slight dependence in this respect was observed in Austria, Finland, Portugal, Cyprus, Croatia, Poland, and Romania. By contrast, almost no dependence was shown in Greece, Italy, Slovenia, Northern Macedonia, and Serbia.

(RQ2) The results of the analysis show that, in most of the studied countries, there was a statistically significant positive correlation between the increase in GDP per capita and the use of renewable energy sources. Weak and moderate correlations were found for Austria, Finland, Portugal, Cyprus, Croatia, Poland, and Romania. No correlation was found in Greece, or North Macedonia, one of the countries most exposed to energy poverty; it showed almost no correlation.

(RQ2) In about half of the countries analysed, there was also a somewhat negative correlation between the degree of renewable energy use and the inability to maintain a comfortable temperature in the home. The more the use of green energy increased, the 
more the degree of energy poverty, measured as the inability to heat the home, decreased. Such a correlation was not observed in Greece, Norway, or Slovenia.

(QR2) Analysis of the correlation between household expenditure on electricity, gas, and other fuels, and the share of renewable energy in gross energy consumption revealed a quite strong negative relationship between these variables in half of the countries analysed. By contrast, a moderate relationship was found in Finland, Italy, Portugal, Spain, Sweden, Cyprus, Poland, and Slovakia. No correlation was found in Greece, France, Norway, Romania, or Slovenia. On the other hand, in Serbia and North Macedonia, there was a positive correlation in this regard.

\section{Discussion and Limitations}

Based on research, as well as analysis of the literature, energy poverty is closely related to income poverty. Fuel poverty affects quality of life, while a lack of access to modern energy sources contributes to an increase in the consumption of conventional energy, and thus to carbon dioxide emissions and greater environmental pollution. Fuel poverty is exacerbated by job loss and falling wages. This is particularly evident among people and households with the lowest and average incomes. The need to use heating appliances, and the increasing number of domestic appliances that use energy to power the home, increase bills, although an increasing number of these appliances, if they are of the new generation of designs, have a lower energy demand. The size and surface area of a dwelling and its energy efficiency have important effects on fuel poverty.

The consequences of fuel poverty are directly related to health. However, they are also linked to other areas, including social exclusion, poor well-being, and lower chances for educational achievement [63]. Solving the problem of energy poverty, or at least reducing it, would contribute, to a large extent, to reduced medical expenses for citizens, a better quality of life, and/or increased economic activity [30]. The size and number of energy-excluded households, or those classified as energy-poor, have many causes and are influenced by many, varied factors. The inability to maintain adequate levels of heat results in health problems for families living in poorly heated flats or houses. In addition, low air temperatures also negatively affect housing conditions, which only get worse from season to season. Situations related to the lack of funds for payments create a kind of loop, constantly worsening the situation of households. In general, the socioeconomic consequences of energy poverty relate to economic development in both the short and long term, reducing productivity in the agricultural sector, preventing socioeconomic progress, or negatively affecting the education of children and young people [36]. Lack of funds for energy charges, or the lack of funds for necessary repairs caused by energy poverty-this situation, unfortunately, often loops from year to year-causes more problems. Energy poverty can be influenced by household characteristics, socioeconomic factors, and environmental factors (including climatic conditions and climate change). This means that a holistic approach is required to seek solutions to minimise energy poverty, considering all the characteristics and factors identified. Indicators of the statistical incidence of energy poverty in individual member states do not reflect the regulatory and policy commitments of national energy and climate plans [32]. This is also apparent in the results of the studies carried out.

Poverty can be understood both in the microeconomic context (e.g., households), as well as in the macroeconomic context, relating to the whole economy and its implications concerning, inter alia, the use of renewable energy, the construction of support systems for modern solutions, and, consequently, environmental protection and the achievement of sustainable development goals.

The limitation of the study is that it adopts a very general approach to the problem. Many cases of spatial inequalities within national economies have already been described in the literature and the study was limited to one selected indicator. The article does not deal with many aspects that will be subject to further scientific exploration. The research was limited to environmental aspects of sustainable development and aspects related to 
macroeconomic factors. Social and economic aspects were not considered, as well as trends, or the impact of factors such as the use of technology in households to meet needs, such as those for education, food, or even medicine. These aspects have become particularly important during the COVID-19 pandemic. A further limitation of the study is omission of the energy efficiency of buildings, which can have a very high impact on heat loss and contribute to fuel poverty.

The results of the research are interesting. There is a clear correlation indicating that relatively poorer countries with higher levels of energy poverty are closing the gap faster over the years.

\section{Conclusions}

Reducing energy poverty can have a positive impact on the environment; lack of access to energy resources, such as electricity and LPG, obstructs growth and development and will have a huge impact on the environment. Access to affordable and clean energy resources is crucial for the eradication of poverty and the promotion of overall wellbeing [64].

- In a territorial context, Eastern and Southern European countries were more vulnerable to energy poverty. There were high levels of overall income poverty, inefficient housing, inadequate infrastructure development, and various governance challenges $[32,65,66]$, but these countries are rapidly reducing the proportion of households defined as and affected by energy poverty. These measures should therefore be linked to increased use of renewable, environmentally friendly energy. The creation of policies and documents and the implementation of tools that contribute to reducing energy poverty are becoming incentives for practical action in this area. Energy poverty is related not only to economic but also to non-economic factors. The cost of energy is forecast to rise, which means that, if not addressed, fuel poverty is likely to increase. Using appropriate measurement techniques and best practice, it is possible to counteract negative phenomena, assisting people, regions, or sectors that are vulnerable to the climate change associated with the transition to a low-carbon economy. Eradicating energy poverty is only possible if a long-term, energy-efficiencyoriented policy on the use of renewable energy in households is introduced [34]. It is not only access to resources and energy that is important, but also its efficient use, and policies that contribute to increasing the quality of life and creating an energy poverty alleviation effect. Directions of environmental policy development must be correlated with economic development and global trends. Despite a high level of economic development, European countries are struggling with the problem of energy poverty. There are many reasons for this. As studies and statistics show, more and more households are affected by this problem, so it is necessary to take measures to prevent it. Our analysis and correlations, using data from 37 European economies, show that the use of modern, renewable energy had a positive impact on several of the components of fuel poverty, such as inability to heat the home. On the other hand, this energy is not cheap and a very significant role in its promotion and implementation is played by the state with its management tools and instruments. The contribution and novelty of the discussion provided is also the broad comparative analysis, not limited to just one economy or group of politically and economically connected countries, but a holistic approach showing the problems and determinants of their emergence across Europe. Another element is that it also links (by showing a perspective in terms of comparisons over several years) how the situation has changed in individual countries and whether, for the countries that have joined and are currently operating within the EU structures, this fact has been relevant in terms of changes in energy poverty. This article fills an existing gap in the field. Firstly, although there is a vast literature on energy poverty, there is no comparative study conducted on such a large research sample (37 countries). In addition, econometric methods have been used for this purpose and the economic aspect has been addressed by analysing the situation in 
different countries in the context of political-economic links. There are many studies in this field, but few that deal with such a broad spectrum of countries.

- Appropriate changes in the implementation of energy and climate policy, increasing the use of renewable energy through appropriate government actions, and regulations allowing for a transition to cleaner sources of energy not only help in the fight against climate change but also lead to the alleviation of energy poverty and its scale. This means that, for example, by using new technologies, implementing the energy transformation, and/or using modern financial tools based on ESG criteria, contributions to reducing the problem can be made. It is, therefore, necessary to take several different actions that, in the long term, will contribute to eradicating energy poverty and achieving UN Sustainable Development Goal 7, which seeks to ensure access to affordable, reliable, and modern energy for all by 2030. This means that, at the same time, energy poverty must be reduced through metering, and sustainable development goals must be met. This is possible with understanding and strong public support of the sustainability goals, but also with the availability of modern energy. Actions need to be joint, pursuing common goals. Studies have clearly shown which countries in Europe have large or moderate problems with this phenomenon. The countries with low levels of energy poverty should therefore serve as good examples. Their experience, solutions, and methods of implementation should be used by countries with a smaller income that have not fully implemented programmes for the use of energy from renewable sources. A common path to eliminating the negative phenomena associated with energy poverty can fit perfectly into the realm of sustainable development for the whole of Europe. Countries in a weaker economic position should have access to tools, programmes, and policies to tackle energy poverty while implementing modern tools that contribute to social, economic, and environmental development.

Author Contributions: Conceptualization, B.T., A.B. and M.U.; methodology B.T., A.B. and M.U.; validation, B.T., A.B. and M.U.; formal analysis, B.T., A.B. and M.U.; investigation, B.T., A.B. and M.U.; resources, B.T., A.B. and M.U.; data curation, B.T., A.B. and M.U.; writing-original draft preparation, B.T., A.B. and M.U.; writing-review and editing, B.T., A.B. and M.U. All authors have read and agreed to the published version of the manuscript.

Funding: Text editing was funded by the framework of the program of the Polish Minister of Science and Higher Education under the name "Regional Excellence Initiative" 2019-2022; project number 001/RID/2018/19; the amount of financing PLN 10,684,000.00.

Data Availability Statement: Not applicable.

Conflicts of Interest: The authors declare no conflict of interest.

\section{References}

1. Available online: https://www.worldbank.org/en/topic/energy/overview (accessed on 15 September 2021).

2. EU. Energy Poverty Observatory. 2020. Available online: https://energy-poverty.ec.europa.eu/index_en (accessed on 15 September 2021).

3. Sadath, A.C.; Acharya, R. Assessing the extent and intensity of energy poverty using Multidimensional Energy Poverty Index: Empirical evidence from households in India. Energy Policy 2017, 102, 540-550. [CrossRef]

4. Bhide, A.; Monroy, C.R. Energy poverty: A special focus on energy poverty in India and renewable energy technologies. Renew. Sustain. Energy Rev. 2011, 15, 1057-1066. [CrossRef]

5. Robinson, C.; Bouzarovski, S.; Lindley, S. 'Getting the measure of fuel poverty': The geography of fuel poverty indicators in England. Energy Res. Soc. Sci. 2018, 36, 79-93. [CrossRef]

6. Charlier, D.; Kahouli, S. From Residential Energy Demand to Fuel Poverty: Income-induced Non-linearities in the Reactions of Households to Energy Price Fluctuations. Energy J. 2019, 40. [CrossRef]

7. Snyder, H. Literature review as a research methodology: An overview and guidelines. J. Bus. Res. 2019, 104, 333-339. [CrossRef]

8. Bowen, G.A. Document Analysis as a Qualitative Research Method. Qual. Res. J. 2009, 9, 27-40. [CrossRef]

9. Balakrishnan, N. (Ed.) Methods and Applications of Statistics in Business, Finance, and Management Science; John Wiley \& Sons: Hoboken, NJ, USA, 2010.

10. Wood, M. Making statistical methods in management research more useful: Some suggestions from a case study. arXiv 2009, arXiv:0908.0067. [CrossRef] 
11. Brundtland, G.H. Our Common Future-Call for Action. Environ. Conserv. 1987, 14, 291-294. [CrossRef]

12. Parris, T.M.; Kates, R.W. Characterizing and measuring sustainable development. Annu. Rev. Environ. Resour. 2003, 28, 559-586. [CrossRef]

13. Available online: https:/ / ec.europa.eu/eurostat/web/sdi/indicators (accessed on 15 September 2021).

14. Available online: https://ec.europa.eu/eurostat/statistics-explained/index.php?title=Glossary:Sustainable_development_ indicator_(SDI) (accessed on 15 September 2021).

15. United Nations. Transforming Our World: The 2030 Agenda for Sustainable Development; United Nations: New York, NY, USA, 2015.

16. Available online: https://www.un.org/sustainabledevelopment (accessed on 25 October 2021).

17. Boardman, B. Fuel Poverty: From Cold Homes to Affordable Warmth; Belhaven Press: London, UK, 1991.

18. Heindl, P.; Schuessler, R. Dynamic properties of energy affordability measures. Energy Policy 2015, 86, 123-132. [CrossRef]

19. Phimister, E.; Vera-Toscano, E.; Roberts, D.J. The Dynamics of Energy Poverty: Evidence from Spain. Econ. Energy Environ. Policy 2015, 4, 153-166. [CrossRef]

20. Okushima, S. Measuring energy poverty in Japan, 2004-2013. Energy Policy 2016, 98, 557-564. [CrossRef]

21. Pachauri, S.; Mueller, A.; Kemmler, A.; Spreng, D. On Measuring Energy Poverty in Indian Households. World Dev. 2004, 32, 2083-2104. [CrossRef]

22. Public Health England. The Cold Weather Plan for England: Protecting Health and Reducing Harm from Cold Weather; Public Health England: London, UK, 2018.

23. Scottish Fuel Poverty Definition Review Panel. A New Definition of Fuel Poverty in Scotland: A Review of Recent Evidence; Scottish Government: Edinburgh, UK, 2017.

24. Bouzarovski, S. Energy poverty in the European Union: Landscapes of vulnerability. Wiley Interdiscip. Rev. Energy Environ. 2013, 3, 276-289. [CrossRef]

25. Hills, J. Getting the Measure of Fuel Poverty: Getting the Measure of Fuel Poverty: Final Report of the Fuel Poverty Review; Hills Review Fuel Poverty: London, UK, 2012.

26. Stelmach, G.; Zanocco, C.; Flora, J.; Rajagopal, R.; Boudet, H.S. Exploring household energy rules and activities during peak demand to better determine potential responsiveness to time-of-use pricing. Energy Policy 2020, 144, 111608. [CrossRef]

27. Middlemiss, L. A critical analysis of the new politics of fuel poverty in England. Crit. Soc. Policy 2016, 37, 425-443. [CrossRef]

28. Reddy, A. Energy and social issues. In World Energy Council and UNEP; Energy and the Challenge of Sustainability: New York, NY, USA, 2000.

29. Day, R.; Walker, G.P.; Simcock, N. Conceptualising energy use and energy poverty using a capabilities framework. Energy Policy 2016, 93, 255-264. [CrossRef]

30. Biernat-Jarka, A.; Trębska, P.; Jarka, S. The Role of Renewable Energy Sources in Alleviating Energy Poverty in Households in Poland. Energies 2021, 14, 2957. [CrossRef]

31. Scarpellini, S.; Hernández, M.A.S.; Moneva, J.M.; Portillo-Tarragona, P.; Rodríguez, M.E.L. Measurement of spatial socioeconomic impact of energy poverty. Energy Policy 2019, 124, 320-331. [CrossRef]

32. Bouzarovski, S.; Thomson, H.; Cornelis, M. Confronting Energy Poverty in Europe: A Research and Policy Agenda. Energies 2021, 14, 858. [CrossRef]

33. Nagaj, R.; Korpysa, J. Impact of COVID-19 on the Level of Energy Poverty in Poland. Energies 2020, 13, 4977. [CrossRef]

34. Streimikiene, D.; Lekavičius, V.; Baležentis, T.; Kyriakopoulos, G.L.; Abrhám, J. Climate change mitigation policies targeting households and addressing energy poverty in European union. Energies 2020, 13, 3389. [CrossRef]

35. Mamica, Ł.; Głowacki, J.; Makieła, K. Determinants of the Energy Poverty of Polish Students during the COVID-19 Pandemic. Energies 2021, 14, 3233. [CrossRef]

36. Halkos, G.; Gkampoura, E.-C. Coping with Energy Poverty: Measurements, Drivers, Impacts, and Solutions. Energies 2021, 14, 2807. [CrossRef]

37. Karpinska, L.; Śmiech, S. Escaping Energy Poverty: A Comparative Analysis of 17 European Countries. Energies 2021, 14, 5761. [CrossRef]

38. Healy, J.D.; Clinch, J.P. Fuel poverty in Europe: A cross-country analysis using a new composite measurement. In Environmental Studies Research Series Working Papers; University College Dublin: Dublin, Ireland, 2002.

39. Roberts, D.; Vera-Toscano, E.; Phimister, E. Fuel poverty in the UK: Is there a difference between rural and urban areas? Energy Policy 2015, 87, 216-223. [CrossRef]

40. Villalobos, C.; Chávez, C.; Uribe, A. Energy poverty measures and the identification of the energy-poor: A comparison between the utilitarian and capability-based approaches in Chile. Energy Policy 2021, 152, 112146. [CrossRef]

41. Hills, J. Getting the measure of fuel poverty. In Final Report of the Energy Poverty Review, Case Report No. 72, Commissioned by the UK Department of Energy and Climate Change; DECC: London, UK, 2012.

42. Ambrose, A.R. Improving energy efficiency in private rented housing: Why don't landlords act? Indoor Built Environ. 2015, 24, 913-924. [CrossRef]

43. Recalde, M.; Peralta, A.; Oliveras, L.; Tirado-Herrero, S.; Borrell, C.; Palncia, L.; Marí-Dell'Olmo, M. Structural energy poverty vulnerability and excess winter mortality in the European Union: Exploring the association between structural determinants and health. Energy Policy 2019, 133, 110869. [CrossRef] 
44. Sokołowski, J.; Lewandowski, P.; Kiełczewska, A.; Bouzarovski, S. Measuring Energy Poverty in Poland with the Multidimensional Energy Poverty Index; In IBS Working Paper 07/2019; 2019. Available online: https:/ /ibs.org.pl/en/publications/measuringenergy-poverty-in-poland-with-the-multidimensional-energy-poverty-index/ (accessed on 15 September 2021).

45. Rademaekers, K.; Yearwood, J.; Ferreira, A.; Pye, S.; Hamilton, I.; Agnolucci, P.; Anisimova, N. Selecting Indicators to Measure Energy Poverty under the Pilot Project 'Energy Poverty'-Assessment of the Impact of the Crisis and Review of Existing and Possible New Measures in the Member States; Framework Contract ENER A, 4; Trinomics: Rotterdam, The Netherlands, 2016.

46. Thomson, H.; Simcock, N.; Bouzarovski, S.; Petrova, S. Energy poverty and indoor cooling: An overlooked issue in Europe. Energy Build. 2019, 196, 21-29. [CrossRef]

47. Bouzarovski, S.; Herrero, S.T. The energy divide: Integrating energy transitions, regional inequalities and poverty trends in the European Union. Eur. Urban Reg. Stud. 2017, 24, 69-86. [CrossRef] [PubMed]

48. Dubois, U.; Meier, H. Energy affordability and energy inequality in Europe: Implications for policymaking. Energy Res. Soc. Sci. 2016, 18, 21-35. [CrossRef]

49. Thema, J.; Vondung, F. EPOV Indicator Dashboard: Methodology Guidebook; Wuppertal Institut für Klima, Umwelt, Energie GmbH: Wuppertal, Germany, 2020. Available online: https://energy-poverty.ec.europa.eu/system/files/2021-09/epov_methodology_ guidebook_1.pdf (accessed on 15 September 2021).

50. Gordon, D.; Adelman, L.; Ashworth, K.; Bradshaw, J.; Levitas, R.; Middleton, S.; Pantazis, C.; Patsios, D.; Payne, S.; Townsend, P.; et al. Poverty and Social Exclusion in Britain; Joseph Rowntree Foundation: York, UK, 2000.

51. Healy, J.D.; Clinch, J. Quantifying the severity of fuel poverty, its relationship with poor housing and reasons for non-investment in energy-saving measures in Ireland. Energy Policy 2004, 32, 207-220. [CrossRef]

52. Healy, J. Housing, Fuel Poverty and Health: A Pan-European Analysis; Ashgate: Aldershot, UK, 2004.

53. Petrova, S.; Gentile, M.; Mäkinen, I.H.; Bouzarovski, S. Perceptions of Thermal Comfort and Housing Quality: Exploring the Microgeographies of Energy Poverty in Stakhanov, Ukraine. Environ. Plan. A Econ. Space 2013, 45, 1240-1257. [CrossRef]

54. Thomson, H.; Snell, C. Quantifying the prevalence of fuel poverty across the European Union. Energy Policy 2013, 52, 563-572. [CrossRef]

55. Piekut, M. Patterns of Energy Consumption in Polish One-Person Households. Energies 2020, 13, 5699. [CrossRef]

56. Bossert, W.; Chakravarty, S.R.; D'Ambrosio, C. Measuring Multidimensional Poverty: The Generalized Counting Approach; The Social Sciences and Humanities Research Council of Canada: Ottawa, ON, Canada, 2009.

57. Nussbaumer, P.; Bazilian, M.; Modi, V. Measuring energy poverty: Focus on what matters. Renew. Sustain. Energy Rev. 2012, 16, 231-243.

58. Alkire, S.; Foster, J. Counting and multidimensional poverty measurement. J. Public Econ. 2011, 95, 476-487.

59. Thomson, H.; Bouzarovski, S.; Snell, C. Rethinking the measurement of energy poverty in Europe: A critical analysis of indicators and data. Indoor Built Environ. 2017, 26, 879-901. [CrossRef]

60. De Arce, R.; Mahía, R. Drivers of Electricity Poverty in Spanish Dwellings: A Quantile Regression Approach. Energies 2019, 12, 2089. [CrossRef]

61. Adom, P.K.; Amuakwa-Mensah, F.; Agradi, M.P.; Nsabimana, A. Energy poverty, development outcomes, and transition to green energy. Renew. Energy 2021, 178, 1337-1352. [CrossRef]

62. Eurostat. Available online: https:/ / ec.europa.eu/eurostat (accessed on 15 September 2021).

63. Rugkåsa, J.; Shortt, N.; Boydell, L. Engaging Communities: An Evaluation of a Community Development Model for Tackling Rural Fuel Poverty; Institute of Public Health in Ireland: Belfast, UK, 2004.

64. Acharya, R.H.; Sadath, A.C. Energy poverty and economic development: Household-level evidence from India. Energy Build. 2018, 183, 785-791. [CrossRef]

65. Buzar, S. Energy Poverty in Eastern Europe: Hidden Geographies of Deprivation; Ashgate: Aldershot, UK, 2007.

66. Healy, J. Fuel Poverty and Policy in Ireland and the European Union; Policy Institute, Trinity College Dublin: Dublin, Ireland, 2003. 